\title{
A Study on In Vitro Propagation Possibilities of Some Clone Rootstocks of Prunus Species
}

\author{
Mine Pakyurek (Corresponding author) \\ Siirt University, Faculty of Agriculture, Department of Horticulture, 56100, Siirt, Turkey \\ E-mail: mine.pakyurek@siirt.edu.tr \\ Serra Hepaksoy \\ Ege University, Faculty of Agriculture, Department of Horticulture, 35100, Izmir, Turkey \\ E-mail: serra.hepaksoy@ege.edu.tr
}

This study was produced from the PhD thesis of Mine Aksehirli Pakyurek and funded by Ege University Scientific Research Projects Office with the project number 07-ZRF-002.

\begin{abstract}
In vitro techniques which is one of the modern breeding methods offer alternative methods to meet the growing food demands in parallel with the increasing world population by allowing rapid and intensive mass propagation of varieties and rootstocks in fruit cultivation under laboratory conditions. Clone rootstocks which are economically important and early yielding with maximum yield per unit area are preferred in fruit production. In this study, the propagation possibilities of Marianna GF 8/1, Myrobolan B, Myrobolan 29-C and St Julien A clone rootstocks used in the production of stone fruit species were investigated. In this study, shoot tips were used as explants. MS (Murashige-Skoog) media was used as the propagation media and $30 \mathrm{~g} \mathrm{~L}^{-1}$ sucrose and $7 \mathrm{~g} \mathrm{~L}^{-1}$ agar were added. The shoot tips were planted into the media and then placed in the temperature and light controlled culture chamber. Samples were placed to the subculture at 1-month intervals. Explant length, number of leaves and number of tillings were observed every 20 days. Nine different MS media were tested during the shoot growth stage. The best propagation was obtained in the $1 \mathrm{mg} \mathrm{L}^{-1} \mathrm{BAP}+0.5 \mathrm{mg} \mathrm{L}^{-1} \mathrm{IBA}+0.25 \mathrm{mg} \mathrm{L}^{-1} \mathrm{GA} 3$ media. Eight different MS media were tested during the rooting stage. The best rooting was achieved in a media containing $1 / 2 \mathrm{MS}+2 \mathrm{mg} \mathrm{L}^{-1} \mathrm{IBA}$.
\end{abstract}

Keywords: Marianna GF 8/1, Myrobolan B. Julien A, Myrobolan 29-C, micropropagation, plant growth regulators.

DOI: $10.7176 / \mathrm{JSTR} / 5-9-10$

\section{Prunus Türlerine Ait Bazı Klon Anaçlarının In Vitro Çoğaltma Olanakları Üzerine Bir Çalışma}

Özet

Her geçen gün artan dünya nüfusuna paralel olarak büyüyen gıda ihtiyacını karşılamakta alternatif yeni yöntemler sunan ve bitki biyoteknolojisi adı altında toplanan modern sslah yöntemlerinden in vitro teknikler meyvecilik alanında üretilmek istenen çeşit ve anaçların laboratuvar koşullarında hızlı ve yoğun bir biçimde kitlesel olarak çoğaltılmasına olanak tanımaktadır. Meyve üretiminde ekonomik açıdan önemli olan erken ürüne yatma ve birim alandan maksimum verim elde etme özelliklerine sahip klon anaçları tercih edilmektedir. Bu çalışmada sert çekirdekli meyve türlerinin üretiminde kullanılan Marianna GF 8/1, Myrobolan B, Myrobolan 29-C ve St. Julien A klon anaçlarının doku kültürü ile çoğaltılma olanakları araştırılmıştır. Çalışmada eksplant olarak sürgün uçları kullanılmıştır. Besin ortamı olarak MS (Murashige-Skoog) ortamı kullanılmış, $30 \mathrm{~g} \mathrm{~L}^{-1}$ sakkaroz, $7 \mathrm{~g} \mathrm{~L}^{-1}$ agar eklenmiştir. Sürgün uçları besin ortamına dikildikten sonra sıcaklık ve ışık kontrolü olan kültür odasına konulmuştur. Örnekler 1 ay aralıklarla alt kültüre alınmıştır. Her 20 günde eksplant boyu, yaprak sayısı ve kardeşlenme 
sayısı gözlemlenmiştir. Sürgün çoğalması aşamasında 9 farklı MS ortamı denenmiştir. En iyi çoğalma 1 mg L ${ }^{-1} \mathrm{BAP}+0.5 \mathrm{mg} \mathrm{L}^{-1} \mathrm{IBA}+0.25 \mathrm{mg} \mathrm{L}^{-1} \mathrm{GA}_{3}$ ilave edilen ortamda elde edilmiştir. Köklendirme aşamasında 8 farklı MS ortamı denenmiştir. En iyi köklenme ise $1 / 2 \mathrm{MS}+2 \mathrm{mg} \mathrm{L}^{-1}$ IBA içeren besin ortamında sağlanmıştır.

Anahtar Kelimeler: Marianna GF 8/1, Myrobolan B, St. Julien A, Myrobolan 29-C, mikroçoğaltım, bitki büyüme düzenleyiciler.

\section{Giriş}

Meyve yetiştiriciliğinde doğru anaç ve çeşit seçimi üretim kalitesini doğrudan etkileyen en önemli unsurlardan biri olduğu için tüm dünyada ve ülkemizde çeşide en uygun anacin geliştirilmesi ve kullanımı amacıyla yapılan çalışmalara önem verilmektedir. Özellikle sık dikime yönelik toprak ve iklim koşullarına uygun anaç geliştirme çalışmaları yoğun bir şekilde yürütülmektedir. Anaçlar, çoğaltım şekillerine göre iki grupta incelenmektedir. Tohumla çoğaltılanlar "tohum anacı", vejetatif olarak çoğaltılanlar ise "klon anacı" olarak adlandırılmaktadır. Heterozigotik yapıda olmaları nedeniyle açılım göstermeleri, aşırı kuvvetli büyümeleri ve geç verime yatmaları tohum anaçlarının olumsuz yönleridir. Bunun yanı sıra bazı çöğürler ağır topraklarda gelişememekte ve özellikle Phytophthora Kök Çürüklüğü Hastalığına karşı oldukça hassasiyet göstermektedir (Hartmann ve Kester, 1983). Klon anaç kullanımıyla genotipin devamlılığı sağlanmakta, bir örnek bir populasyon yapısı oluşturulabilmekte ve gençlik kısırlığı döneminin kısaltılması ile ağaç daha erken meyveye yatmaktadır (Hartmann ve Kester, 1983). Günümüzde Prunus türlerinin üretiminde hem çöğür hem de klon anaçları kullanılmaktadır. Örneğin; erik üretiminde çöğür anacı olarak can eriklerinin yabani formları olan Myrobolan anaçları tercih edilmektedir. Klon anacı olarak da Myrobolan 29-C, Myrobolan B, Myrobolan GF 31, Marianna 2624, Marianna GF 8-1, Saint Julien A, Saint Julien 655/2, Pixy ve şeftali ile badem melezi olan GF 677 anaçları kullanılmaktadır (Anonim, 2008c). Bir başka sert çekirdekli meyve türü olan kayısı yetiştiriciliğinde de anaç olarak derin, geçirgen, su tutmayan, besin maddelerince zengin, tınlı veya tınlıkireçli topraklar için kayısı çöğürleri kullanılmakla beraber kumlu topraklarda kayısı yetiştirilmek istendiğinde anaç olarak şeftali çögürlerinin kullanılması daha kaliteli ürün alınmasını sağlamaktadır. Ayrıca ağır topraklarda yapılacak yetiştiricilik için ise Myrobolan (can erikleri) anaçları tercih edilmektedir (Anonim, 2008b).

Doku kültürü yöntemlerinden biri olan mikroçoğaltım tekniği, tam bir bitki oluşturabilme potansiyeline sahip bitki kısımlarından (embriyo, tohum, gövde, kök, sürgün, kallus, tek hücre veya polen tanesi vb.) alınan doku parçalarının yapay besin ortamında mikroorganizmalardan arındırılmış şartlar altında genetik olarak birbirine benzeyen çok sayıda bitkiyi hızlı çoğaltma amacıyla kullanılan bir tekniktir. Mikroçoğaltım tekniği, ziraat ve orman mühendisliğinin çalışma alanı içinde yer alan birçok bitki türü üzerinde uygulanmaktadır (Solarova ve Posposilova, 1997; Nguyen ve Kozai, 1998; Pospisilova ve ark., 1999; Mansuroğlu ve Gürel, 2001). Mikroçoğaltımın başarısı, çoğaltım için kullanılan bitki parçasının (eksplant) alındığı bitkinin genotipi, sağlık durumu ile beslenme, sşık, sıcaklık, bitki büyüme düzenleyicilerinin uygulanması ve yetişme mevsimi gibi yetiştirme koşullarından doğrudan etkilenmektedir. Bitkinin, vejetatif gelişme evresinde olması da mikroçoğaltımın başarılı olmasını sağlayan bir başka faktördür. Vejetasyon periyodu içinde farklı dönemlerde alınan eksplantların kalitesi, çevresel faktörlerin etkisine bağlı olarak değişebilmektedir. Bu nedenle eksplantların, sürgün gelişiminin hızlı olduğu ve aktif büyümenin gerçekleştiği dönemlerde alınmasına özen gösterilmelidir (Debergh ve Read, 1993). Bu tekniğin temel safhaları; eksplant alınacak bitkinin seçimi, bitki örneklerinin alınması, örneklerin dikime hazırlığ 1 ve besin ortamlarının hazırlığı adımlarını içeren hazırlık safhası, eksplantların yapay besin ortamlarına dikiminin yapıldığı kültür safhası, kültür ortamı içerisinde sürgün çoğaltım ve gelişimi safhası, köklendirme safhası ve dış ortama adaptasyon safhası şeklinde sıralanmaktadır (George ve ark., 2008).

Son yıllarda gelişmiş ülkelerde sert çekirdekli meyve türleri için kullanılan klon anaçları virüsten ari şekilde doku kültürü teknikleri ile yoğun olarak üretilmektedir (Muna ve ark., 1999; Ertürk ve ark., 2007). Türkiye'de de Tarım Bakanlığı bünyesinde bulunan araştırma enstitüleri ve özel sektöre bağlı laboratuvarlarda doku kültürü tekniği ile klon anacı üretimi yaygın hale gelmeye başlamıştır. Bununla birlikte hala mevcut üretim ihtiyaçlarının karşılanması için klon anaçlarının dış pazardan ithaline devam edilmektedir. Ülkemizde biyoteknolojik yöntemleri kullanarak klon anacı üretiminin ülke ihtiyaçları ölçüsünde arttırılması ve yaygınlaştırılması anaçlık materyalin yurtdışından ithalini önleyecek ve üretimdeki girdi maliyetlerini azaltacaktır. Bu düşünceden hareket ederek yapılan bu çalışmada Marianna GF 8/1, Myrobolan B, Myrobolan 29-C ve Saint Julien A klon anaçlarının in vitro çoğaltma koşullarının belirlenmesi amaçlanmıştır.

66 | $P$ a g e

www.iiste.org 


\section{Materyal ve Metod}

\subsection{Materyal}

Araştırma, 2007-2009 yılları arasında Ege Üniversitesi Ziraat Fakültesi Bahçe Bitkileri Bölümü Doku Kültürü Laboratuvarında yürütülmüştür. Isparta Eğirdir Meyvecilik Araştırma Enstitüsü’nde ismine doğru olarak üretilmiş Marianna GF 8/1, Myrobolan B, Myrobolan 29-C ve St. Julien A klon anaçlarından alınan sürgün uçları çalışmada eksplant olarak kullanılmıştır.

Marianna anaçları, Prunus cerasifera ve Prunus munsoniana'nın doğal melezlemesi sonucu Kaliforniya'da üretilmiştir. Bu gruptaki anaçların en önemlileri Marianna 2624 ve Marianna GF 8/1 dir. $\mathrm{Bu}$ çalışmada kullanılan Marianna GF 8/1 anacı yüzeysel kök oluşturur. Ağır ve nemli topraklarda yetişebildiği gibi, kumlu kireçli topraklarda çok iyi sonuç vermektedir. Bu anaç, Phytophythora ve meşe kök mantarı hastalıklarına toleranslı, kök ur nematoduna dayanıklı, bakteriyel kanser ve kök uru hastalıklarına ise hassastır. Çok verimli ağaçlar oluşturur. Odun çelikleri ve daldırma metodu ile kolay çoğaltılabilir. Marianna GF 8/1, tüm erik çeşitleri ile uyuşma göstermekle birlikte bazı şeftali, nektarin ve badem çeşitleri ile uyuşmazlık görülmektedir (Anonim, 1969; Hartmann ve Kester, 1983).

Myrobolan klon anaçları, Prunus cerasifera türünden İngiltere'de East Malling Araştırma Enstitüsü'nde geliştirilen Myrobolan A, B, C ve D anaçlarıdır. Bunlardan Myrobolan A, C ve D orta kuvvette ağaç meydana getirmekte ve ticari olarak kullanılmaktadır. Myrobolan B ise, özellikle Kuzey Avrupa grubu erikler için ticari olarak kullanılmaktadır. Bu gruptaki anaçlar değişik toprak tiplerine adapte olabilme, orta derinlikte kök meydana getirme, kuvvetli ve büyük ağaçlar oluşturma özelliğine sahiptir. Bunun yanı sıra geç meyveye yatmasına rağmen on yıldaki toplam verimi St. Julien A klon anacından daha yüksektir. Ayrıca kök ur nematoduna dayanıklı, bakteriyel kanser ve meşe kök mantarına hassastır (Büyükyılmaz ve Öz, 1994).

St. Julien A ise Prunus institia L. erik türünden elde edilmiştir. Yarı bodur olan bu klon anac1, ağır bünyeli toprakları sevmez. Aşırı soğuklara dayanıksız olup, drenajı iyi olan topraklarda önerilir. Üzerine aşılanan çeşidin verimi üzerine olumlu etki eder, Phytophythora ve bakteriyel kanser hastalıklarına dayanıklıdır. Erik türlerinin yanı sıra şeftali, nektarin ve kayısıda da anaç olarak kullanılabilir. İngiltere ve İspanya'da kullanımı yaygındır (Büyükyılmaz ve Öz, 1994).

\subsection{Yöntem}

Bu çalışmada, MS (Murashige ve Skoog, 1962) besin ortamı kullanılmıştır. Daha önce bu konuda yapılmış çalışmaların literatür bilgileri doğrultusunda, MS besin ortamına değişik bitki büyüme düzenleyicilerinin farklı konsantrasyonları uygulanmıştır. Bitki büyüme düzenleyicisi olarak oksin grubundan, indol butirik asit (IBA) ve naftalen asetik asit (NAA); gibberellin grubundan, gibberellik asit (GA3); sitokinin grubundan, 6-benzilaminopürin (BAP) kullanılmıştır. Besin ortamlarına $30 \mathrm{~g} / \mathrm{L}$ sakkaroz ile başlangıç aşamasında $7 \mathrm{~g} / \mathrm{L}$, köklenme aşamasında ise $6 \mathrm{~g} / \mathrm{L}$ agar eklenmiştir. Steril saf su ile hazırlanan besin ortamlarının pH değerleri, $1 \mathrm{~N}$ Sodyum Hidroksit $(\mathrm{NaOH})$ ve $1 \mathrm{~N}$ Hidroklorik Asit (HCL) kullanılarak ayarlanmıştır. Önceden sterilizasyonu yapılmış cam tüp veya kavanozlara konulan besin ortamları $121{ }^{\circ} \mathrm{C}$ 'de 1,2 atmosfer basınçtaki otoklavda $20 \mathrm{dk}$ süre ile tutulup sterilizasyon işleminden geçirilmiştir. Çalışmanın sürgün çoğaltma aşamasında dokuz, köklendirme aşamasında ise sekiz adet MS besin ortamı kullanılmış olup bu ortamların adları, bitki büyüme düzenleyici içerikleri, pH dereceleri ve kaynak bildirimleri aşağıda Çizelge 2.1 ve 2.2 ' de verilmiştir.

\subsubsection{Bitki örneklerinin alınması, dikime hazırlanması ve sterilizasyonu}

Mayıs ayında sabah erken saatlerde bitkilerden alınan sürgün ucu örnekleri, dokularda oluşacak su kaybını azaltmak amacıyla ıslak kağıtlara sarılarak, naylon poşetlere konulmuş ve buzluk içinde laboratuvara getirilmiştir. Bitki örneklerindeki küçük yapraklar, sürgün uçlarına zarar vermeyecek şekilde uzaklaştırılmış ve ardından çeşme suyu ile yıkanarak materyalin mikroorganizma yoğunluğu azaltılmıştır. Bu şekilde kaba kirinden arındırılan bitki örnekleri daha sonra sabunlu suya konulup, burada ara sıra karıştırılarak $20 \mathrm{dk}$ bekletildikten sonra akan çeşme suyu altında $20 \mathrm{dk}$ yıkanmış ve ön sterilizasyon işlemi tamamlanmıştır. Ön sterilizasyon işleminden sonra laminar (yatay ve dikey düzlemde steril) hava akışlı kabine alınan örnekler, $20 \mathrm{dk}$ süre ile \% 4 sodyum hipoklorit içeren 1/5 oranında seyreltilmiş çözeltide bekletilerek sterilize edilmiştir. Daha sonra üç kez beşer dakika süre ile steril saf suda yıkanıp dezenfektan madde uzaklaştırılarak sterilizasyon işlemi tamamlanmış ve eksplantlar besin ortamlarına dikilmek üzere hazır hale getirilmiştir (Karvar ve Gülşen, 1990). 


\subsubsection{In vitro kültür koşulları}

In vitro koşullarda kültüre alınan eksplantlar, başlangıç, çoğaltma ve köklendirme aşamalarında $24 \pm 1{ }^{\circ} \mathrm{C}$ sıcaklık ve 16 saat ışık, 8 saat karanlık koşullarda kültür odasında tutulmuştur. Kültür kabı olarak kullanılan cam tüplerin ağızları kendilerine ait kapaklar ile cam kavanoz ve petrilerin ağızları ise streç film ile kapatıldığından kültür odasında nem kontrolü yapılmamıştır.

\subsubsection{Deneme planı ve verilerin analizi}

Sürgün çoğaltma ve köklendirme aşamalarında denemeler tesadüf parselleri deneme desenine göre her kültür kabında 5 eksplant olacak şekilde, 3 tekerrürlü olarak petri ve kavanoz kurulmuştur. Elde edilen verilerin ortalama değerlerine göre besin ortamları ve ölçüm zamanları arasındaki farklılıklar ile ortam $x$ zaman arasındaki interaksiyonlar varyans analizi yöntemi (ANOVA) ile Minitab Paket Programı (MINITAB) kullanılarak F-testine göre kontrol edilmiştir $(\mathrm{P}<0.05)$. Ortaya çıkan önemli farklılıklar Duncan Testi ile $\% 5$ hata sınırı esas alınarak saptanmıştır. İstatistik analizlerde yüzde oranlarının açı değeri karşılıkları kullanılmıştır.

Cizelge 2.1. Sürgün çoğaltma așamasında kullanılan MS besin ortamları

\begin{tabular}{|c|c|c|c|}
\hline $\begin{array}{c}\text { Ortam } \\
\text { Adı }\end{array}$ & Bitki Büyüme Düzenleyici İçeriği & pH & Kaynak \\
\hline S 1 & $\mathrm{MS}+1 \mathrm{mg} \mathrm{L}^{-1} \mathrm{BAP}+0.1 \mathrm{mg} \mathrm{L}^{-1} \mathrm{NAA}$ & 5.6 & Özzambak ve Hepaksoy, 1997a \\
\hline $\mathrm{S} 2$ & $\mathrm{MS}+1 \mathrm{mg} \mathrm{L}^{-1} \mathrm{BAP}+0.1 \mathrm{mg} \mathrm{L}^{-1} \mathrm{NAA}+0.1 \mathrm{mg} \mathrm{L}^{-1} \mathrm{GA} 3$ & 5.6 & Ruzic ve ark., 1998 \\
\hline S 3 & $\mathrm{MS}+1 \mathrm{mg} \mathrm{L}^{-1} \mathrm{BAP}+0.1 \mathrm{mg} \mathrm{L}^{-1} \mathrm{IAA}+0.1 \mathrm{mg} \mathrm{L}^{-1} \mathrm{GA} 3$ & 5.6 & ----- \\
\hline S 4 & $\mathrm{MS}+2 \mathrm{mg} \mathrm{L}^{-1} \mathrm{BAP}+0.1 \mathrm{mg} \mathrm{L}^{-1} \mathrm{IBA}+0.25 \mathrm{mg} \mathrm{L}^{-1} \mathrm{GA} 3$ & 5.6 & Hepaksoy, 2004 \\
\hline S 5 & $\mathrm{MS}+1 \mathrm{mg} \mathrm{L}^{-1} \mathrm{BAP}+0.5 \mathrm{mg} \mathrm{L}^{-1} \mathrm{IBA}+0.25 \mathrm{mg} \mathrm{L}^{-1} \mathrm{GA} 3$ & 5.6 & Hepaksoy ve Tanrı sever, 2004 \\
\hline S 6 & $\mathrm{MS}+4.4 \mathrm{mM} \mathrm{BAP}+0.49 \mathrm{mM} \mathrm{IBA}+0.29 \mathrm{mM} \mathrm{GA} 3$ & 5.6 & Espinosa ve ark., 2006 \\
\hline S 7 & $\mathrm{MS}+4.4 \mathrm{mM} \mathrm{BAP}+0.49 \mathrm{mM} \mathrm{IBA}+0.29 \mathrm{mM} \mathrm{GA} 3+1 \mathrm{mM}$ PG & 5.6 & Hammatt ve Grant, 1997 \\
\hline S 8 & $\mathrm{MS}+1 \mathrm{mg} \mathrm{L}^{-1} \mathrm{BAP}$ & 5.6 & ---- \\
\hline S 9 & $\mathrm{MS}+1 \mathrm{mg} \mathrm{L}^{-1} \mathrm{BAP}$ & 6.2 & Özzambak ve Schmidt, 1991 \\
\hline
\end{tabular}

Cizelge 2.2. Köklendirme aşamasında kullanılan MS besin ortamları

\begin{tabular}{|c|l|c|l|}
\hline Ortam Adı & \multicolumn{1}{|c|}{ Bitki Büyüme Düzenleyici İçeriği } & pH & \multicolumn{1}{|c|}{ Kaynak } \\
\hline $\mathrm{K} 1$ & $\mathrm{MS}+0.3 \mathrm{mg} \mathrm{L}^{-1} \mathrm{NAA}$ & 5.6 & Kamali ve ark., 2001 \\
\hline $\mathrm{K} 2$ & $\mathrm{MS}+0.3 \mathrm{mg} \mathrm{L}^{-1} \mathrm{NAA}+1.4 \mathrm{mg} \mathrm{L}^{-1}$ Thiamin & 5.6 & Kamali ve ark., 2001 \\
\hline $\mathrm{K} 3$ & $\mathrm{MS}+0.4 \mathrm{mg} \mathrm{L}^{-1} \mathrm{IBA}+0.3 \mathrm{mgL}$ Thiamin & 5.2 & Morini ve Perrone, 2006 \\
\hline $\mathrm{K} 4$ & $\mathrm{MS}+0.5 \mathrm{mg} \mathrm{L}^{-1} \mathrm{IBA}+283.72 \mathrm{mg} \mathrm{L}^{-1} \mathrm{PG}$ & 5.7 & Paul ve Feucht, 1985 \\
\hline $\mathrm{K} 5$ & $\mathrm{MS}+0.5 \mathrm{mg} \mathrm{L}^{-1} \mathrm{NAA}+283.72 \mathrm{mg} \mathrm{L}^{-1} \mathrm{PG}$ & 5.7 & Paul ve Feucht, 1985 \\
\hline $\mathrm{K} 6$ & $\mathrm{MS}+4.90 \mu \mathrm{M} \mathrm{IBA}_{\mathrm{K}}$ & 5.8 & Pevalek-Kozlina ve Jelaska, 1987 \\
\hline $\mathrm{K} 7$ & $1 / 2 \mathrm{MS}+2 \mathrm{mg} \mathrm{L}^{-1} \mathrm{IBA}$ & 5.6 & Tang ve ark., 2002 \\
\hline $\mathrm{K} 8$ & $1 / 2 \mathrm{MS}+2 \mathrm{mg} \mathrm{L}^{-1} \mathrm{NAA}$ & 5.6 & Tang ve ark., 2002 \\
\hline
\end{tabular}

\section{Bulgular}

\subsection{Başlangıç ve Çoğaltma Aşaması}

Vegetatif gelişmenin devam ettiği mayıs ayı başında alınan sürgün uçları sterilizasyon işleminden geçirilerek sürgün çoğalması için 9 farklı MS besin ortamına dikilmiştir. Çalışmada yer alan anaçların kültür ortamına alınmasından sonra kültürlerde oluşan enfeksiyon, doku kararması ve kuruma sebebiyle materyalde bazı kayıplar meydana gelmiştir. Ancak bu kayıplar çalışmanın devam etmesini engelleyecek düzeyde olmadığı için deneme geriye kalan sağlıklı kültürler ile yürütülmüştür. Ayrıca kültürlerde zaman zaman camsılaşma sorunu görülmüştür. Bu sorun da önemli düzeyde olmadığ 1 için herhangi bir uygulama yapılmamıştır. İlk dikilen kültürler (Şekil 3.1) 4 hafta ara ile alt kültüre alınarak çoğaltma işlemi yapılmış ve yeterli in vitro sürgün elde edildikten sonra ortam denemelerine başlanmıştır. $\mathrm{Bu}$ 
aşamada kurulan 60 günlük denemede yeni besin ortamlarına aktarılan mikro sürgünlerde sürgün boyu, yaprak sayısı ve kardeşlenme sayısı ölçülmüş ve bu ölçümler 0. (denemenin başladığı gün), 20., 40. ve 60. günlerde yapılmıştır. Bu üç parametreye ait bulguların istatistik analizleri ve yorumları aşağıda ilgili anacın adı altında verilmiştir.

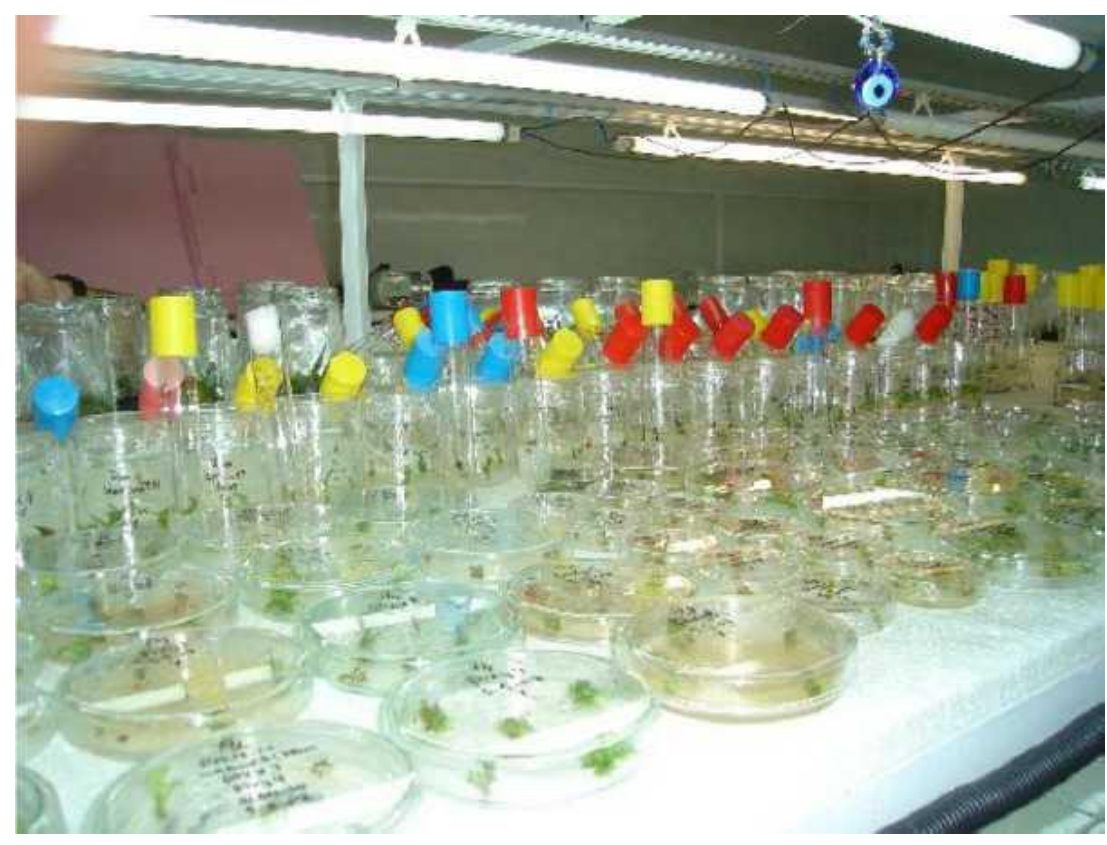

Sekil 3.1. Sürgün çoğaltma așamasında in vitro kültürler

\subsubsection{Marianna GF $8 / 1$ anac1}

$\mathrm{Bu}$ anacın, bitki büyüme düzenleyici içerikleri farklı olan $9 \mathrm{MS}$ besin ortamındaki sürgün gelişimi dikimden itibaren 60 gün boyunca izlenmiştir. 60 gün süresince besin ortamlarında elde edilen ortalama sürgün boyu değerleri Çizelge 3.1' de görülmektedir. Ortalama sürgün boyu açısından ortamlar arasındaki farklılık ve ortam $\mathrm{x}$ zaman interaksiyonu istatistiksel $(\mathrm{P}<0.05)$ olarak önemli bulunmuştur.

Çizelge 3.1. Marianna GF 8/1 anacının besin ortamlarına göre ortalama sürgün boyları (mm)

\begin{tabular}{|c|c|c|c|c|}
\hline \multirow{2}{*}{ Ortam } & \multicolumn{4}{|c|}{ Ortalama Sürgün Boyu (mm) } \\
\cline { 2 - 5 } & 0. gün & 20.gün & 40.gün & 60.gün \\
\hline S 1 & $15.13 \mathrm{bc}$ & $15.40 \mathrm{abc}$ & $17.00 \mathrm{abc}$ & $18.33 \mathrm{abc}$ \\
\hline S 2 & $16.00 \mathrm{abc}$ & $18.80 \mathrm{abc}$ & $21.60 \mathrm{ab}$ & $24.67 \mathrm{a}$ \\
\hline S 3 & $15.13 \mathrm{bc}$ & $19.47 \mathrm{abc}$ & $19.07 \mathrm{abc}$ & $19.67 \mathrm{abc}$ \\
\hline S 4 & $13.47 \mathrm{bc}$ & $15.47 \mathrm{abc}$ & $11.47 \mathrm{c}$ & $11.67 \mathrm{c}$ \\
\hline S 5 & $14.13 \mathrm{bc}$ & $16.27 \mathrm{abc}$ & $17.53 \mathrm{abc}$ & $0.00 \mathrm{~d}$ \\
\hline S 6 & $15.27 \mathrm{bc}$ & $17.47 \mathrm{abc}$ & $18.93 \mathrm{abc}$ & $13.80 \mathrm{bc}$ \\
\hline S 7 & $13.53 \mathrm{bc}$ & $16.20 \mathrm{abc}$ & $17.13 \mathrm{abc}$ & $19.53 \mathrm{abc}$ \\
\hline S 8 & $13.67 \mathrm{bc}$ & $13.60 \mathrm{bc}$ & $15.53 \mathrm{abc}$ & $16.60 \mathrm{abc}$ \\
\hline S 9 & $17.00 \mathrm{abc}$ & $19.33 \mathrm{abc}$ & $21.67 \mathrm{ab}$ & $22.27 \mathrm{ab}$ \\
\hline
\end{tabular}

Marianna GF 8/1 anacı için besin ortamına göre ortalama sürgün boyu açısından 60 günlük ortalama değerler dikkate alındığında 11,98 mm ile S5 ortamında en zayıf gelişme gerçekleşmiştir. En iyi sonuç ise S2 ortamında elde edilmiştir. Bu ortamda ortalama sürgün boyu $20.27 \mathrm{~mm}$ olarak belirlenmiştir. Bu ortamı S9, S3, S7, S1, S6, S8 ve S4 ortamları izlemiştir. Anacın in vitro sürgünlerinin, 60 gün boyunca kademeli olarak gösterdiği gelişim ortamlar bazında incelediğinde $\mathrm{S} 1, \mathrm{~S} 2, \mathrm{~S} 7$ ve S9 ortamlarında, düzenli 
bir gelişmenin devam ettiği görülmektedir. Buna karşılık, S3 ve S4 ortamlarında sürgün gelişimi 20. güne kadar artmış, bugünden sonra S3 ortamında bazı sürgünlerin büyüme uçlarında meydana gelen kurumalar, S4 ortamında ise bazı sürgünlerde ölümlerin olması nedeniyle 40. gündeki ortalama sürgün boyu değerlerinde düşüşler olmuştur. Ancak bu ortamlarda, sağlıklı kalan bitkilerde gelişmenin seyri iyi olduğu için 60. gün değerinde yeniden bir artış gözlenmiştir. S5 ve S6 ortamlarında ise, 40. güne kadar sürgün gelişimi devam etmiş, bundan sonra bitkilerde ölümler meydana gelmeye başlamıştır. Bu ölümler sonucunda S5 ortamında 60 gün sonunda canlı sürgün kalmazken, S6 ortamında az sayıda sürgün canlı kalmış ve 60 . gün sonunda ortalama sürgün boyu değeri 13.80 mm' ye düşmüştür. S8 ortamında ise, ilk kültüre alınma tarihinden itibaren ilk 20 günde sürgün uçlarında kurumalar meydana gelmiş; ancak, canlı kalan sürgünler iyi gelişme gösterdiği için ortalama sürgün boyu değeri artış göstermiştir. Marianna GF 8/1 anac1 için en uzun ortalama sürgün boyuna S1 (18.33 mm), S2 (24.67 mm), S3 (19.67 mm), S 7 $(19.53 \mathrm{~mm}), \mathrm{S} 8(16.60 \mathrm{~mm})$ ve S9 $(22.27 \mathrm{~mm})$ ortamlarında 60 . günde; S5 $(17.53 \mathrm{~mm})$ ve S6 (18.93 $\mathrm{mm})$ ortamlarında 40. günde ve S4 $(15.47 \mathrm{~mm})$ ortamında ise 20 . günde ulaşıldığı görülmektedir. Bunun yanında en kısa ortalama sürgün boyu değeri ise S4 ortamında 40. günde $11.47 \mathrm{~mm}$ olmuştur. Denemenin başlangıcından 60. güne kadar, Marianna GF 8/1 anacı için, S1 ortamında 15.13 mm'den 18.33 mm'ye yükselen ortalama sürgün boyu değeri ile yaklaşı olarak \% 20 oranında bir sürgün uzaması sağlanırken, bu oran, S2 ortaminda \% 50, S3 ortaminda \% 30, S7 ortamında \% 45, S8 ortaminda \% 22 ve S9 ortaminda ise \% 31 olmuştur. S4, S5 ve S6 ortamlarında ise, deneme boyunca sürgün uzamasında düzenli bir artış gözlenmezken, S5 ortamında deneme sonunda hiç canlı sürgün kalmamıştır. S4 ve S6 ortamlarında ise değişik zamanlarda ölümler meydana geldiği için başlangıç değerlerinin de altında olan ortalama değerler oluşmuştur.

Yapılan istatistiki değerlendirmeye göre, mikro sürgünlerin ortalama yaprak sayıları ortamlar açısından bir farklılık göstermezken, zamana ve ortam x zaman interaksiyonuna göre istatistiki olarak fark göstermektedir $(\mathrm{P}<0.05)$. Elde edilen ortalama yaprak sayıları Çizelge 3.2' de verilmiştir.

Marianna GF 8/1 anacı için ortalama yaprak sayıları zamana göre incelendiğinde düzenli bir artış göstermiştir. Deneme başında 7.82 adet/eksplant olan değer, 20. günde 9,05 adet/eksplant, 40. günde 9.48 adet/eksplant ve 60 . günde ise 10,10 adet/eksplant değerine ulaşmıştır. Mikro sürgünlerin ortalama yaprak sayılar1, sürgün boyu değerleri gibi 60 gün boyunca S1, S2, S3, S7, S8 ve S9 ortamlarında düzenli olarak artarken S4 ortamında 20. güne kadar artış göstermiştir. Bugünden sonra bitkilerde meydana gelen ölümler nedeniyle bu değer 40. günde azalmış; ancak, sağlıklı kalan bitkilerde gelişme iyi olduğu için 60. gün değerinde yeniden bir artış gözlenmiştir. S5 ortamında ise in vitro sürgünlerde 40. güne kadar yaprak oluşumu devam etmiştir. Bundan sonra sürgünlerin tamamında ölümler meydana gelmesi nedeniyle 60. gün sonunda canlı sürgün kalmamıştır. S6 ortamında ise 40. güne kadar ortalama değerlerde artış görülmüş, sonrasında bazı mikro sürgünlerin ölmesi nedeniyle ortalama yaprak sayısı değerinde azalma olmuştur.

Çizelge 3.2. Marianna GF 8/1 anacının besin ortamlarına göre ortalama yaprak sayıları (adet/eksplant)

\begin{tabular}{|c|c|c|c|c|}
\hline \multirow{2}{*}{ Ortam } & \multicolumn{4}{|c|}{ Ortalama yaprak sayısı (adet/eksplant) } \\
\cline { 2 - 5 } & 0. gün & $\mathbf{2 0 . g u ̈ n}$ & 40.gün & 60.gün \\
\hline S 1 & $7.53 \mathrm{abcd}$ & $8.27 \mathrm{abcd}$ & $9.33 \mathrm{abcd}$ & $10.27 \mathrm{abcd}$ \\
\hline S 2 & $8.07 \mathrm{abcd}$ & $9.60 \mathrm{abcd}$ & $11.13 \mathrm{abcd}$ & $12.53 \mathrm{ab}$ \\
\hline S 3 & $7.13 \mathrm{abcd}$ & $10.20 \mathrm{abcd}$ & $10.47 \mathrm{abcd}$ & $10.93 \mathrm{abcd}$ \\
\hline S 4 & $7.60 \mathrm{abcd}$ & $8.80 \mathrm{abcd}$ & $6.53 \mathrm{~cd}$ & $6.73 \mathrm{bcd}$ \\
\hline S 5 & $9.80 \mathrm{abcd}$ & $11.00 \mathrm{abcd}$ & $11.87 \mathrm{abcd}$ & $0.00 \mathrm{e}$ \\
\hline S 6 & $7.53 \mathrm{abcd}$ & $9.47 \mathrm{abcd}$ & $10.33 \mathrm{abcd}$ & $6.80 \mathrm{abcd}$ \\
\hline S 7 & $6.27 \mathrm{~d}$ & $8.27 \mathrm{abcd}$ & $8.80 \mathrm{abcd}$ & $10.47 \mathrm{abcd}$ \\
\hline S 8 & $7.33 \mathrm{abcd}$ & $8.93 \mathrm{abcd}$ & $10.27 \mathrm{abcd}$ & $11.13 \mathrm{abcd}$ \\
\hline S 9 & $9.13 \mathrm{abcd}$ & $10.80 \mathrm{abcd}$ & $12.13 \mathrm{abc}$ & $12.60 \mathrm{a}$ \\
\hline
\end{tabular}

Bir diğer ifade ile bu ortamlarda deneme süresince yaprak oluşumu ve gelişmesi devam etmiştir. S5 ortamında 11.87 adet/eksplant ve S6 ortamında 10.33 adet/eksplant ile 40. günde, S4 ortamında ise 8.80 adet/eksplant ile 20. günde en yüksek değerlere ulaş1lmıştır. Eksplant başına düşen en az ortalama yaprak sayısının ise S4 ortamında 40. günde 6.53 adet/eksplant olduğu belirlenmiştir. Deneme süresince

70 | P a g e

www.iiste.org 
ortalama yaprak sayıs1 S1 ortamında 7.53 adet/eksplant değerinden 10.27 adet/eksplant değerine yükselerek yaklaşık olarak \% 36 oranında artış gösterirken; bu artış S2 ortamında $\% 50$, S3 ortamında $\%$ $53, \mathrm{~S} 7$ ortamında $\% 63, \mathrm{~S} 8$ ortamında $\% 54$ ve S9 ortamında ise $\% 38$ oranında olmuştur. Sürgün gelişimine paralel olarak yine S4, S5 ve S6 ortamlarında mikro sürgünlerde meydana gelen ölümler nedeniyle ortalama yaprak sayısında bir artış gözlenememiştir.

In vitro koşullarda Marianna GF 8/1 anacının ortalama kardeşlenme sayıları açısından, ortama, zamana ve ortam x zaman interaksiyonuna göre bazı farklılıklar belirlenmekle birlikte bu farklılıklar istatistiki olarak önemsiz bulunmuştur. Ortalama kardeşlenme sayıları Çizelge 3.3' te görülmektedir.

Çizelge 3.3. Marianna GF 8/1 anacinın besin ortamlarına göre ortalama kardeșlenme sayıları (adet/eksplant)

\begin{tabular}{|c|c|c|c|}
\hline Ortam & \multicolumn{3}{|c|}{ Ortalama kardeşlenme (adet/eksplant) } \\
\hline & 20. gün & 40. gün & 60. gün \\
\hline S 1 & 0.33 & 0.60 & 1.27 \\
\hline S 2 & 0.73 & 1.40 & 2.47 \\
\hline S 3 & 0.33 & 0.40 & 0.93 \\
\hline S 4 & 0.67 & 1.07 & 1.67 \\
\hline S 5 & 0.73 & 1.53 & 0.00 \\
\hline S 6 & 0.47 & 0.67 & 0.93 \\
\hline S 7 & 0.73 & 0.67 & 1.33 \\
\hline S 8 & 0.67 & 0.33 & 0.87 \\
\hline S 9 & 0.73 & 1.20 & 1.93 \\
\hline
\end{tabular}

Her üç parametre birlikte incelendiğinde en başarılı ortamlar S2, S7, S9, S3 ve S8 olmuştur. Bu ortamları $\mathrm{S} 1$ ortamı takip etmiştir. Başarısı daha düşük olan ortamlar ise S5, S4 ve S6'dır. Şekil 3.1'de anacın S2 ve S5 ortamlarındaki gelişme durumu görülmektedir.
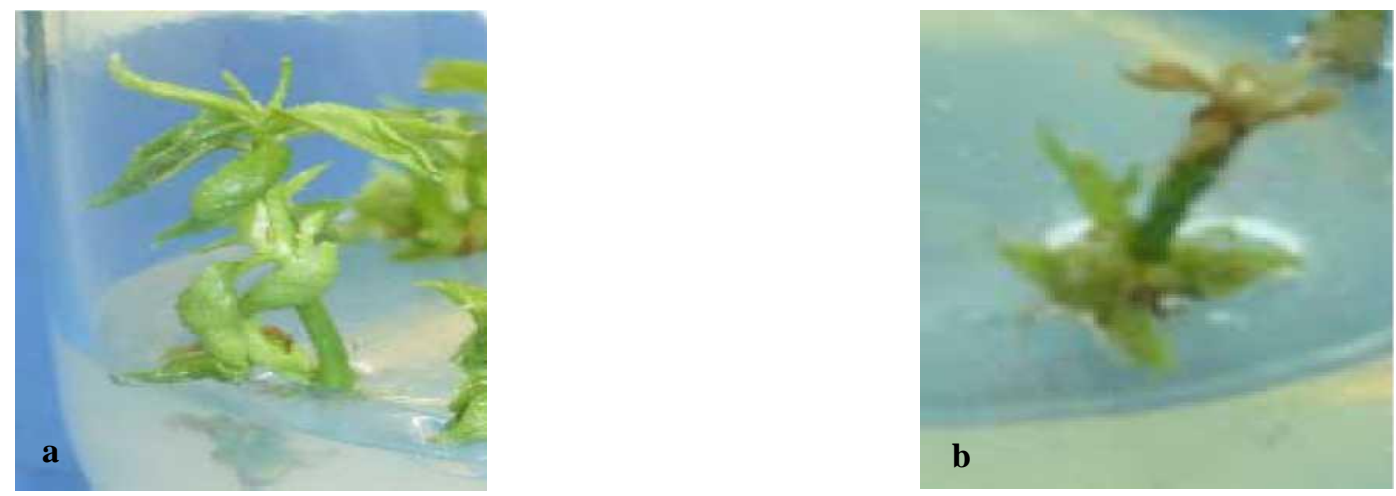

Șekil 3.1. Marianna GF 8/1 anacının S2 (a) ve S5 (b) ortamlarında 5. hafta sonundaki gelișme durumu.

\subsubsection{Myrobolan B anac1}

Bu anacın, bitki büyüme düzenleyici içerikleri farklı olan 9 MS besin ortamındaki sürgün gelişimi 60 gün boyunca izlenmiştir. Sürgün boyu bakımından ortamın, zamanın ve ortam x zaman arasındaki interaksiyonun etkisi $(\mathrm{P}<0.05)$ istatistiksel açıdan önemli bulunmuştur. Elde edilen ortalama değerler Çizelge $3.4^{\prime}$ te görülmektedir. Besin ortamına göre ortalama sürgün boyları değerlendirildiğinde S6 ortamının $18.27 \mathrm{~mm}$ değeri ile ilk sırada yer aldığı; bunu S5, S9, S2, S1, S8, S3, S7 ortamlarının takip ettiği ve $8.40 \mathrm{~mm}$ değeri ile en az ortalama sürgün boyunun $\mathrm{S} 4$ ortamına ait olduğu görülmektedir.

$\mathrm{Bu}$ anaç için 0 . gün ölçülen ortalama sürgün boyu $13.67 \mathrm{~mm}$ iken; bu değer 20 . günde $15.59 \mathrm{~mm}, 40$. günde $15.41 \mathrm{~mm}$ ve 60 . günde ise $12.47 \mathrm{~mm}$ olmuştur. Ortalama sürgün boyu değerleri 20. güne kadar yükselme göstermiş ve bugünden sonra sürgünlerde meydana gelen kuruma ve ölümler nedeniyle 40 .

71 I P a g e www.iiste.org 
gün ve 60. gün ortalama değerleri düşmüştür. Myrobolan B anacının sürgün gelişimi 60 günlük deneme boyunca S2, S5, S6 ve S9 ortamlarında düzenli olarak artmıştır. Buna karş1lık S1 ve S4 ortamlarında sürgün gelişimi 20. güne kadar artmış, bugünden sonra mikro sürgünlerin uçlarında meydana gelen kuruma ve sürgünlerin ölmesi nedeniyle 40. günde ortalama sürgün boyu değeri azalmış, ancak sağlıklı kalan bitkilerde gelişme iyi olduğu için 60. gün değerinde yeniden bir artış gözlenmiştir. S3, S7 ve S8 ortamlarında ise 40. güne kadar ortalama değerlerde artış olurken; sonrasında S3 ve S7 ortamlarında kuruyan ve S8 ortamında ise ölen mikro sürgünler nedeniyle ortalama sürgün boyu değerinde azalma görülmüştür.

Çizelge 3.4. Myrobolan B anacının besin ortamlarına göre ortalama sürgün boyu (mm) değerleri

\begin{tabular}{|c|c|c|c|c|}
\hline \multirow{2}{*}{ Ortam } & \multicolumn{4}{|c|}{ Ortalama Sürgün Boyu (mm) } \\
\cline { 2 - 5 } & $\mathbf{0 . \text { gün }}$ & $\mathbf{2 0 . g u ̈ n}$ & $\mathbf{4 0 . g u ̈ n}$ & 60.gün \\
\hline S 1 & $13.87 \mathrm{abc}$ & $14.27 \mathrm{abc}$ & $13.40 \mathrm{abc}$ & $15.00 \mathrm{abc}$ \\
\hline S 2 & $12.33 \mathrm{bc}$ & $14.33 \mathrm{abc}$ & $16.33 \mathrm{abc}$ & $19.60 \mathrm{ab}$ \\
\hline S 3 & $13.40 \mathrm{abc}$ & $15.20 \mathrm{abc}$ & $15.67 \mathrm{abc}$ & $9.13 \mathrm{~cd}$ \\
\hline S 4 & $14.47 \mathrm{abc}$ & $14.67 \mathrm{abc}$ & $2.20 \mathrm{~d}$ & $2.27 \mathrm{~d}$ \\
\hline S 5 & $12.80 \mathrm{abc}$ & $15.93 \mathrm{abc}$ & $18.73 \mathrm{ab}$ & $19.60 \mathrm{ab}$ \\
\hline S 6 & $14.60 \mathrm{abc}$ & $18.00 \mathrm{ab}$ & $19.93 \mathrm{ab}$ & $20.53 \mathrm{a}$ \\
\hline S 7 & $12.20 \mathrm{bc}$ & $15.67 \mathrm{abc}$ & $16.67 \mathrm{abc}$ & $3.33 \mathrm{~d}$ \\
\hline S 8 & $14.93 \mathrm{abc}$ & $16.80 \mathrm{abc}$ & $19.00 \mathrm{ab}$ & $4.20 \mathrm{~d}$ \\
\hline S 9 & $14.40 \mathrm{abc}$ & $15.47 \mathrm{abc}$ & $16.73 \mathrm{abc}$ & $18.60 \mathrm{ab}$ \\
\hline
\end{tabular}

En yüksek ortalama sürgün boyunun S1, S2, S5, S6 ve S9 ortamlarında 60. günde, S3, S7 ve S8 ortamlarında 40. günde, S4 ortamında ise 20. günde oluştuğu görülmektedir. En düşük ortalama sürgün boyu değeri ise S4 ortamında 40. günde oluşmuştur. Denemenin başlangıcından 60. güne kadar S1 ortamında $13.87 \mathrm{~mm}$ 'den $15.00 \mathrm{~mm}$ 'ye yükselen ortalama sürgün boyu değeri ile yaklaşı olarak \%8 oranında bir sürgün uzaması sağlanırken; bu oran S2 ortamında $\% 59$, S5 ortamında \%53, S6 ortamında $\% 41$ ve S9 ortamında ise \%29 olmuştur. S3, S4, S7 ve S8 ortamlarında ise deneme boyunca sürgün uzamasında düzenli bir artış gözlenmemiş, S3 ve S7'de bazı sürgünlerin tamamen kuruması ve S4 ve S8'de ise bazı sürgünlerin ölmesinden dolayı deneme sonundaki ortalama değerler başlangıç değerlerinin de altına düşmüştür.

Myrobolan B anacının yaprak sayısı açısından ortamın, zamanın ve ortam x zaman interaksiyonunun etkisi $(\mathrm{P}<0.05)$ istatistiksel olarak önemlidir. Elde edilen ortalama değerler Çizelge 3.5' te verilmiştir.

Cizelge 3.5. Myrobolan B anacının besin ortamlarına göre ortalama yaprak sayıları (adet/eksplant)

\begin{tabular}{|c|c|c|c|c|}
\hline \multirow{2}{*}{ Ortam } & \multicolumn{4}{|c|}{ Ortalama yaprak sayısı (adet/eksplant) } \\
\cline { 2 - 5 } & $\mathbf{0 . \text { gün }}$ & $\mathbf{2 0 . g u ̈ n}$ & $\mathbf{4 0 . g u ̈ n}$ & $\mathbf{6 0 . g u ̈ n}$ \\
\hline S 1 & $8.93 \mathrm{bcdef}$ & $10.33 \mathrm{abcde}$ & $9.67 \mathrm{abcde}$ & $10.80 \mathrm{abcd}$ \\
\hline S 2 & $7.27 \mathrm{def}$ & $8.40 \mathrm{bcdef}$ & $9.73 \mathrm{abcde}$ & $11.67 \mathrm{abcd}$ \\
\hline S 3 & $5.87 \mathrm{efg}$ & $7.80 \mathrm{cdef}$ & $8.00 \mathrm{cdef}$ & $4.67 \mathrm{fgh}$ \\
\hline S 4 & $7.20 \mathrm{def}$ & $7.67 \mathrm{cdef}$ & $0.80 \mathrm{~h}$ & $0.87 \mathrm{~h}$ \\
\hline S 5 & $9.00 \mathrm{bcdef}$ & $10.87 \mathrm{abcd}$ & $12.27 \mathrm{abc}$ & $12.87 \mathrm{ab}$ \\
\hline S 6 & $6.93 \mathrm{def}$ & $8.73 \mathrm{bcdef}$ & $9.80 \mathrm{abcde}$ & $10.33 \mathrm{abcde}$ \\
\hline S 7 & $7.73 \mathrm{cdef}$ & $10.07 \mathrm{abcde}$ & $10.60 \mathrm{abcd}$ & $2.33 \mathrm{gh}$ \\
\hline S 8 & $7.27 \mathrm{def}$ & $8.80 \mathrm{bcdef}$ & $10.73 \mathrm{abcd}$ & $2.53 \mathrm{gh}$ \\
\hline S 9 & $11.20 \mathrm{abcd}$ & $12.20 \mathrm{abc}$ & $12.80 \mathrm{ab}$ & $13.93 \mathrm{a}$ \\
\hline
\end{tabular}


Ortalama yaprak sayısı zamana göre incelendiğinde 20. gün değeri 9.43 adet/eksplant'a yükselirken, 40. gün değeri 9.38 adet/eksplant, 60. gün değeri ise 7.78 adet/eksplant olmuştur. Ortalama değerlerin 20. güne kadar artış gösterdiği; ancak, 40. günden itibaren düştüğü görülmektedir. Besin ortamları bakımından ortalama yaprak sayıları incelendiğinde ise 12.53 adet/eksplant değeri ile S9 ortamının en yüksek ortalama değere ulaştığ1 saptanmıştır. Bu ortamı; S5, S1, S2, S6, S7, S8, S3 ve S4 (4.13 adet/eksplant) ortamlarının izlediği belirlenmiştir. S2, S5, S 6 ve S9 ortamlarında Myrobolan B anacının yaprak sayısı da sürgün boyu gibi 60 gün boyunca düzenli olarak artmıştır. S1 ve S4 ortamlarında ise 20. güne kadar artmış, sonrasında sürgünlerin ucunda meydana gelen kuruma ve sürgünlerdeki ölümler nedeniyle 40. günde ortalama yaprak sayısı değeri azalmıştır. Ancak sağlıklı kalan sürgünlerde gelişme iyi olduğu için 60. gün değerinde yeniden bir artış gözlenmiştir. S3, S7 ve S8 ortamlarında ise 40. güne kadar ortalama değerlerde artış olurken, sonrasında mikro sürgünlerde oluşan kurumalar nedeniyle ortalama değerin azaldığı tespit edilmiştir. Denemede en yüksek ortalama yaprak sayısı değerine S1 (10.80 adet/eksplant), S2 (11.ó7 adet/eksplant), S5 (12.87 adet/eksplant), S6 (10.33 adet/eksplant) ve S9 (13.93 adet/eksplant) ortamlarında 60., S3 (8.00 adet/eksplant), S7 (10.60 adet/eksplant) ve S8 (10.73 adet/eksplant) ortamlarında 40., S4 (7.67 adet/eksplant) ortamında ise 20. günde ulaşıldığı görülmektedir. En düşük ortalama yaprak sayısı ise S4 ortamında 40. günde 0,80 adet/eksplant olmuştur. Ortalama yaprak sayıs1, deneme sonuna kadar S1 ortamında 8,93 adet/eksplant değerinden 10,80 adet/eksplant değerine ulaşarak yaklaşık \%21 oranında bir artış sağlarken bu artış S2 ortamında \%60, S5 ortamında \% 42, S6 ortamında \% 49 ve S9 ortamında ise \% 24 olmuştur. Bu anacın ortalama kardeşlenme sayısı, ortama ve zamana göre farklılık göstermektedir $(\mathrm{P}<0.05)$ ve bu farklılık istatistiksel açıdan önemlidir. Elde edilen ortalama değerler Çizelge 3.6' da verilmiştir.

Cizelge 3.6. Myrobolan B anacının besin ortamlarına göre ortalama kardeșlenme sayıları (adet/eksplant)

\begin{tabular}{|c|c|c|c|c|}
\hline \multirow{2}{*}{ Ortam } & \multicolumn{2}{|c|}{ Ortalama kardeşlenme sayısı (adet/eksplant) } & \multirow{2}{*}{ Ortalama } \\
\cline { 2 - 4 } & $\mathbf{2 0 . g u ̈ n}$ & $\mathbf{4 0 . g u ̈ n}$ & $\mathbf{6 0 . g u ̈ n}$ & \\
\hline S 1 & 0.40 & 0.53 & 0.93 & $0.62 \mathrm{de}$ \\
\hline S 2 & 0.40 & 0.53 & 0.93 & $0.62 \mathrm{de}$ \\
\hline S 3 & 0.20 & 0.20 & 0.60 & $0.33 \mathrm{ef}$ \\
\hline S 4 & 0.07 & 0.00 & 0.00 & $0.02 \mathrm{f}$ \\
\hline S 5 & 0.93 & 1.67 & 2.13 & $1.57 \mathrm{a}$ \\
\hline S 6 & 0.87 & 1.53 & 2.07 & $1.48 \mathrm{ab}$ \\
\hline S 7 & 0.07 & 0.07 & 0.07 & $0.07 \mathrm{f}$ \\
\hline S 8 & 0.13 & 0.33 & 0.13 & $0.20 \mathrm{ef}$ \\
\hline S 9 & 0.53 & 0.33 & 1.47 & $0.77 \mathrm{~cd}$ \\
\hline
\end{tabular}

Zamana göre ortalama kardeşlenme sayıları incelendiğinde, 20. günden itibaren kardeşlenme durumunun düzenli olarak artmıştır. Denemenin 20. gününde 0.44 adet/eksplant olan ortalama kardeşlenme sayısının, 40. günde 0.66 adet/eksplant ve 60 . günde ise 0.96 adet/eksplant değerine yükseldiği görülmektedir. Ortamlar bakımından kardeşlenme durumu incelendiğinde en başarılı sonucu 1.57 adet/eksplant ile S5 ortamı vermiş; bu ortamı S6, S2, S9, S1, S3, S8, S7 ve S4 (0.02 adet/eksplant) ortamları izlemiştir. S1, S2, S3, S5 ve S6 ortamlarında ortalama kardeşlenme sayısı deneme boyunca düzenli bir artış gösterirken; S4 ortamında, 20. güne kadar artmış ve sonrasında bütün sürgünlerin ölmesi sebebiyle geride canlı sürgün kalmamıştır. S7 ve S8 ortamlarında denemenin 20. ve 40. gün değerleri aynı olmuştur. S7'de ilk 20 günde kardeşlenme meydana gelirken daha sonraki günlerde sürgün uçlarındaki kurumalar sebebiyle ortalama kardeşlenme sayısı sabit kalmıştır. S8'de 40. günde artan ortalama kardeşlenme sayısı (0.33 adet/eksplant), sürgünlerin ölmesi yüzünden 60. ve 20. gün değerleri (0.13 adet/eksplant) ile ayn1 olmuştur. S9 ortamında ise 20. gün değerinin artmasının ardından sürgünlerdeki kurumalar nedeniyle 40. gün değeri azalmıştır. Ancak canlı kalan sürgünlerin gelişmesi iyi olduğundan 60. günde yeniden bir artış kaydedilmiştir. Anacın en yüksek ortalama kardeşlenme sayısı 1.57 adet/eksplant ile S5 ve 1,48 adet/eksplant ile S6 ortamlarında elde edilirken; en düşük ortalama kardeşlenme sayıları ise S4 (0.02 adet/eksplant) ve S7 (0.07 adet/eksplant) ortamlarında elde edilmiştir. 
Myrobolan B anacı için, sürgün çoğaltma aşamasında denenen MS besin ortamları farklı ölçüde başarı göstermiştir. Ortamlar sürgün boyu, yaprak sayısı ve kardeşlenme durumu açısından genel olarak değerlendirildiğinde en başarılı olanlar sirasıyla S2, S5, S6 ve S9' dur. S4, S7 ve S3 ortamları ise en az başarı gösteren ortamlardır.
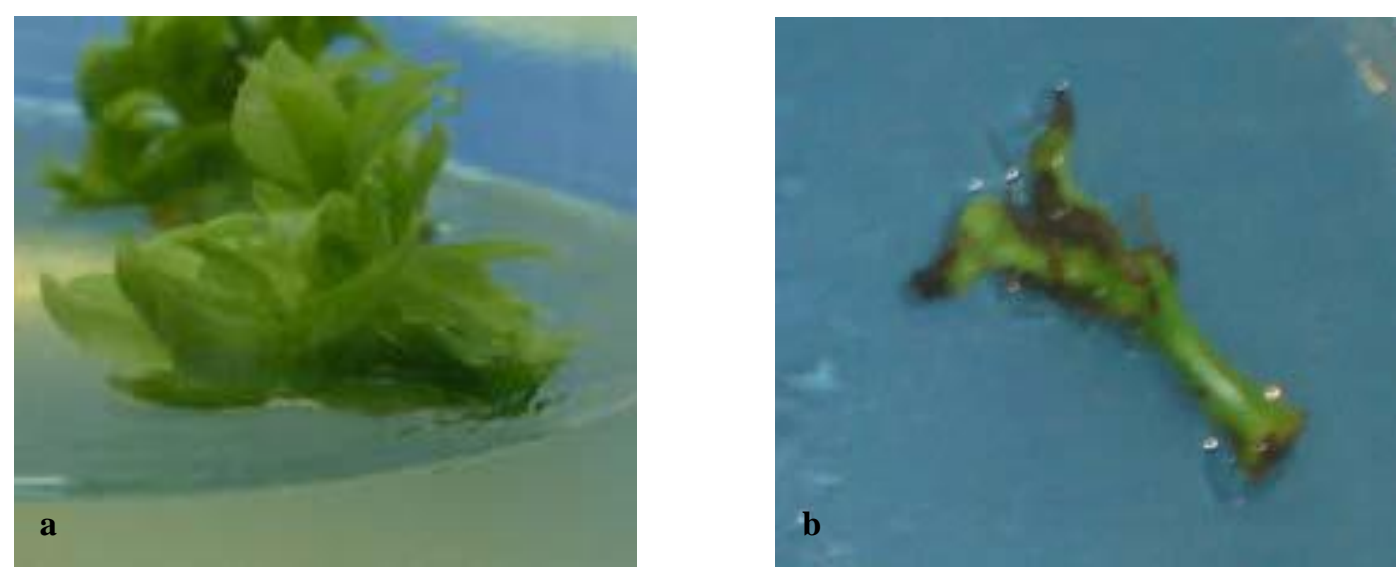

Șekil 3.2. Myrobolan B anacının S2 (a) ve S4 (b) ortamlarında 5. hafta sonundaki gelişme durumu

\subsubsection{Myrobolan 29-C anac1}

Başlangıç ve sürgün çoğaltma aşamasında S2, S3, S4, S6, S7, S8 ve S9 ortamlarında bulunan bu anaca ait mikro sürgünlerin ölmesi nedeniyle 60 günlük deneme, sadece S1 ve S5 ortamlarında kurulabilmiştir. Yapılan varyans analizine göre bu anaçta sürgün gelişimi, ortama göre fark göstermektedir $(\mathrm{P}<0.05)$ ve bu fark istatistiksel açıdan önemlidir. Elde edilen ortalama değerler Çizelge 3.7' de verilmiştir.

Çizelge 3.7. Myrobolan 29-C anacının besin ortamlarına göre ortalama sürgün boyu (mm) değerleri

\begin{tabular}{|c|c|c|c|c|c|}
\hline \multirow{2}{*}{ Ortam } & \multicolumn{4}{|c|}{ Ortalama sürgün boyu (mm) } & \multirow{2}{*}{ Ortalama } \\
\cline { 2 - 5 } & 0. gün & 20.gün & 40.gün & 60.gün & \\
\hline S 1 & 9.47 & 9.73 & 10.67 & 10.47 & $10.08 \mathrm{~b}$ \\
\hline S 5 & 12.20 & 16.40 & 19.60 & 20.93 & $17.28 \mathrm{a}$ \\
\hline
\end{tabular}

$\mathrm{Bu}$ anaçta denenen iki besin ortamından biri olan S5 ortamında ortalama sürgün boyu değerleri deneme sonuna kadar düzenli olarak artmıştır. S1 ortamında ise 40. güne kadar ortalama değerler artmış, daha sonra mikro sürgünlerin ölmesi nedeniyle 60. günde değerler azalmıştır. En uzun sürgün (20,93 mm), S5 ortamında 60. günde elde edilirken, en kısa sürgün $(9,73 \mathrm{~mm})$ ise $\mathrm{S} 1$ ortamında 20. günde oluşmuştur. S5 ortamında ortalama sürgün boyu, deneme başında 12,20 mm iken deneme sonunda 20,93 mm değerine ulaşarak yaklaşık \% 71 oranında bir artış kaydedilmiştir. İki ortam açısından en iyi sürgün uzamas1 17,28 mm ile S5 ortamında elde edilmiştir. S1 ortamı ise sürgün boyu açısından deneme süresince düzenli bir artış göstermemiştir.

Deneme süresinde izlenen mikro sürgünlerin yaprak gelişimi, ortama göre farklılık göstermektedir $(\mathrm{P}<0.05)$ ve bu farklılık istatistiksel açıdan önemlidir. Elde edilen ortalama değerler Çizelge 3.8' de görülmektedir.

Çizelge 3.8. Myrobolan 29-C anacının besin ortamlarına göre ortalama yaprak sayıları (adet/eksplant)

\begin{tabular}{|c|c|c|c|c|c|}
\hline \multirow{2}{*}{ Ortam } & \multicolumn{4}{|c|}{ Ortalama yaprak sayısı (adet/eksplant) } & \multirow{2}{*}{ Ortalama } \\
\cline { 2 - 5 } & 0.gün & 20.gün & 40.gün & 60.gün & \\
\hline S1 & 6.00 & 5.20 & 5.67 & 5.53 & $5.60 \mathrm{~b}$ \\
\hline S5 & 6.27 & 8.60 & 10.40 & 11.20 & $9.12 \mathrm{a}$ \\
\hline
\end{tabular}


S5 ortamındaki ortalama yaprak sayısı, sürgün boyunda olduğu gibi deneme sırasında düzenli olarak artmıştır. S1 ortamında ise deneme başındaki ortalama değer mikro sürgünlerde meydana gelen ölümler nedeniyle 20. günde azalmış, daha sonra canlı kalan sürgünlerde iyi bir gelişme olduğundan 40. gün değeri artmıştır. Ancak yine sürgünlerin ölmesi sebebiyle 60. günde ortalama değer tekrar düşmüştür. En iyi yaprak oluşumu (11.20 adet/eksplant), S5 ortamında 60. günde sağlanırken, en az yaprak (5.20 adet/eksplant) S1 ortamında 20. günde oluşmuştur. S5 ortamında ortalama yaprak sayısı, deneme başında 6.27 adet/eksplant iken deneme sonunda 11.20 adet/eksplant değerine ulaşmış ve yaklaşı \% $\% 9$ oranında bir artış kaydedilmiştir. S1 ortamında ise yaprak oluşumu açısından deneme süresince düzenli bir artış gözlenememiştir

$\mathrm{Bu}$ anacın kardeşlenme sayısı ortam x zaman interaksiyonuna göre fark göstermiştir $(\mathrm{P}<0.05)$ ve bu fark istatistiki olarak önemlidir. Elde edilen ortalama değerler Çizelge 3.9 'da görülmektedir.

Çizelge 3.9. Myrobolan 29-C anacının besin ortamlarına göre ortalama kardeșlenme sayıları (adet/eksplant)

\begin{tabular}{|c|c|c|c|}
\hline \multirow{2}{*}{ Ortam } & \multicolumn{3}{|c|}{ Ortalama kardeşlenme sayısı (adet/eksplant) } \\
\cline { 2 - 4 } & $\mathbf{2 0 . g u ̈ n}$ & $\mathbf{4 0 . g u ̈ n}$ & $\mathbf{6 0 . g u ̈ n}$ \\
\hline S 1 & $0.93 \mathrm{bc}$ & $0.80 \mathrm{bc}$ & $0.80 \mathrm{bc}$ \\
\hline S 5 & $0.73 \mathrm{c}$ & $1.87 \mathrm{ab}$ & $2.47 \mathrm{a}$ \\
\hline
\end{tabular}

Kardeşlenme miktarı zamanla paralel bir artış göstermiştir. 0.83 adet/eksplant olan 20. gün değeri, deneme sonunda 1.63 adet/eksplant olmuştur. Ortalama değerler S5 ortamında, S1 ortamından iki kat daha fazla sürgün çoğalmasının gerçekleştiğini göstermektedir. Bu anacın ortalama kardeşlenme sayısı, S5 ortamında deneme boyunca düzenli olarak artarken S1 ortamında düzenli bir artış göstermemiştir. S1 ortamında 20. günde 0.93 adet/eksplant olan ortalama değer, mikro sürgünlerdeki ölümler nedeniyle 40. günde 0.80 adet/eksplant'a düşmüştür. En iyi ortalama kardeşlenme sayısı (2.47 adet/eksplant), S5 ortamında 60. günde elde edilirken, en düşük ortalama değer (0.80 adet/eksplant) ise S1 ortamında 40. günde sağlanmıştır. S5 ortamında 0.73 adet/eksplant ortalama değeri ile başlayan denemenin 60 . gün değeri 2.47 adet/eksplant olmuştur. Bu anacın ortalama kardeşlenme sayısı, deneme sonunda yaklaşık 23 kat artış göstermiştir. En iyi ortalama kardeşlenme sayısı 1.27 adet/eksplant ile S5 ortamında elde edilmiştir.

Myrobolan 29-C anacının, bu iki besin ortamındaki gelişme durumları değerlendirildiğinde S5 ortamının S1 ortamından daha başarılı sonuç verdiği görülmektedir. Ortamlardaki gelişme durumları Şekil 3.3'te verilmiştir.
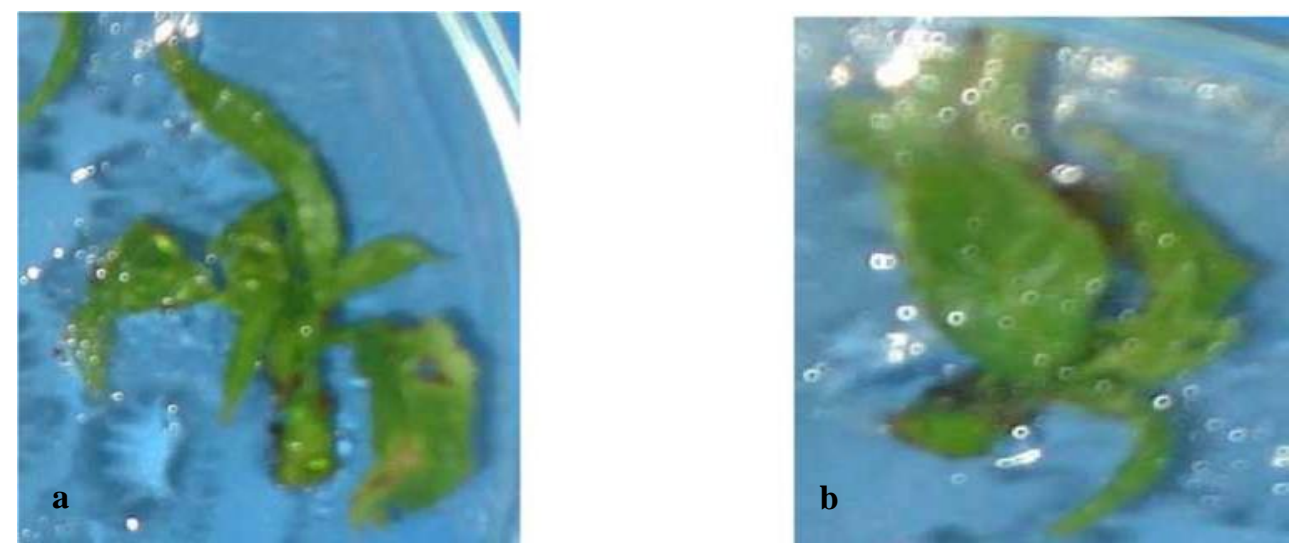

Şekil 3.3. Myrobolan 29-C anacının S5 (a) ve S1 (b) ortamlarında 5. hafta sonundaki gelișme durumu

\subsubsection{St. Julien A anac1}

Mikro sürgün gelişimi 60 gün izlenen bu anacın, sürgün boyu, ortam x zaman interaksiyonuna göre fark göstermektedir $(\mathrm{P}<0.05)$ ve bu fark istatistiksel açıdan önemlidir. Elde edilen ortalama değerler Çizelge

75 | P a g e

www.iiste.org 
3.10'da verilmiştir. Ortamlara göre ortalama sürgün boyu incelendiğinde S3 ortamının $21.32 \mathrm{~mm}$ ortalama sürgün boyu değeri ile en başarılı besin ortamı olarak ilk sırada bulunduğu; bu ortamı, S2, S9, S5, S6, S8, S7, S1 ve S4 (3.43 mm) ortamlarının takip ettiği görülmektedir.

Cizelge 3.10. St. Julien A anacının besin ortamlarına göre ortalama sürgün boyu (mm) değerleri

\begin{tabular}{|c|c|c|c|c|}
\hline \multirow{2}{*}{ Ortam } & \multicolumn{4}{|c|}{ Ortalama sürgün boyu (mm) } \\
\hline & 0. gün & 20. gün & 0. gün & 60. gün \\
\hline S 1 & 10.93 ghij & 10.73 ghij & $9.73 \mathrm{hij}$ & $6.73 \mathrm{jjk}$ \\
\hline S 2 & 14.93 bcdefgh1 & 16.93 bcdefgh & $18.53 \mathrm{bcdefg}$ & $22.33 \mathrm{abcd}$ \\
\hline S 3 & 17.67 bcdefgh & 19.60 abcdef & 21.13 abcdef & $26.87 \mathrm{a}$ \\
\hline S 4 & 13.73 efghij & $0.00 \mathrm{k}$ & $0.00 \mathrm{k}$ & $0.00 \mathrm{k}$ \\
\hline S 5 & 14.33 cdefgh 1 & 14.93 bcdefgh1 & 17.07 bcdefgh & 18.07 bcdefgh \\
\hline S 6 & 13.33 efghij & 15.80 bcdefgh & 17.87 bcdefgh & 14.93 bcdefgh1 \\
\hline S 7 & 12.67 fghij & 15.33 bcdefgh & 13.87 defghıj & $6.07 \mathrm{jk}$ \\
\hline S 8 & 15.13 bcdefgh & 21.27 abcde & $23.20 \mathrm{ab}$ & $0.00 \mathrm{k}$ \\
\hline S 9 & 13.00 efghij & 15.73 bcdefgh & 19.80 abcdef & $22.40 \mathrm{abc}$ \\
\hline
\end{tabular}

Aseptik koşullarda S2, S3, S5, S9 ortamlarında St. Julien A anacının sürgün gelişimi deneme süresince düzenli olarak artmıştır. S7 ortamında $12.67 \mathrm{~mm}$ olan ortalama sürgün boyu 20. günde $15.33 \mathrm{~mm}$ değerine ulaşmış ve bugünden sonra sürgünlerde meydana gelen ölümler nedeniyle 40. günden sonra giderek azalmıştır. S6 ve S8 ortamlarında, 40. güne kadar ortalama değerlerde artış olurken, sonrasında mikro sürgünlerde oluşan ölümler sebebiyle S6 ortamında ortalama değer azalmış, S8 ortamında ise hiç canlı sürgün kalmamıştır. S1 ve S4 ortamlarında ortalama sürgün boyunda herhangi bir artış gözlenmemiştir. S1 ortamında mikro sürgünlerin uçlarında meydana gelen kurumalar nedeniyle değerler sürekli azalırken, S4 ortamında bulunan sürgünler de deneme sonuna kadar canlılığını koruyamamıştır. En yüksek ortalama sürgün boyu değeri S3 ortamında 60. günde $26.87 \mathrm{~mm}$ olurken, en düşük değer S7 ortamında 60. günde $6.07 \mathrm{~mm}$ olmuştur. $\mathrm{Bu}$ anacın, ortalama yaprak sayıları ortam x zaman interaksiyonuna göre fark göstermektedir $(\mathrm{P}<0.05)$ ve bu fark istatistiki açıdan önemlidir. Elde edilen ortalama değerler Çizelge 3.11'de görülmektedir.

Çizelge 3.11. St. Julien A anacının besin ortamlarına göre ortalama yaprak sayıları (adet/eksplant)

\begin{tabular}{|c|c|c|c|c|}
\hline \multirow{2}{*}{ Ortam } & \multicolumn{4}{|c|}{ Ortalama yaprak sayısı (adet/eksplant) } \\
\hline & 0.gün & 20.gün & 40.gün & 60.gün \\
\hline S 1 & $5.80 \mathrm{efgh}$ & $6.13 \mathrm{efgh}$ & $5.67 \mathrm{fgh}$ & $3.87 \mathrm{gh} 1$ \\
\hline S 2 & 7.93 cdefgh & 9.33 abcdef & 10.27 abcdef & $12.40 \mathrm{abcd}$ \\
\hline S 3 & 8.53 abcdefg & 9.40 abcdef & 10.27 abcdef & $13.47 \mathrm{ab}$ \\
\hline S 4 & $5.40 \mathrm{fgh}$ & $0.00_{1}$ & 0.001 & $0.00_{1}$ \\
\hline S 5 & 7.60 cdefgh & 7.93 cdefgh & 9.00 abcdefg & 9.67 abcdef \\
\hline S 6 & 7.40 cdefgh & 9.07 abcdefg & 10.33 abcdef & 8.33 bcdefgh \\
\hline S 7 & 6.73 efgh & 8.80 abcdefg & 7.13 defgh & $3.20 \mathrm{~h} 1$ \\
\hline S 8 & 9.33 abcdef & $12.47 \mathrm{abc}$ & $13.80 \mathrm{a}$ & 0.001 \\
\hline S 9 & 7.00 efgh & 8.67 abcdefg & 11.07 abcde & $12.60 \mathrm{abc}$ \\
\hline
\end{tabular}

Zamana göre ortalama yaprak sayısı incelendiğinde S3 ortamının 10.42 adet/eksplant ortalama yaprak sayısı değeri ile en iyi sonuç veren ortam olduğu, bu ortamı azalan değerlerle S2, S9, S8, S6, S5, S7, S1 ve S4 (10.42 adet/eksplant) ortamlarının izlediği saptanmıştır. Sürgün gelişimine paralel olarak S2, S3, S5 ve S9 ortamlarında ortalama yaprak sayısı değerlerinin düzenli olarak arttığı belirlenmiştir. S1 ve S7 
ortamlarında ortalama yaprak sayısı değerleri 20. güne kadar artmış, bugünden sonra sürgünlerin uçlarında meydana gelen kuruma veya tüm sürgünün ölmesi nedeniyle değerler giderek azalmıştır. S6 ortamında 40. güne kadar ortalama değerlerde artış olurken sonrasında mikro sürgünlerin uçlarındaki kurumalar sebebiyle değerlerde azalma görülmüştür. S8 ortamında 40. güne kadar ortalama değerlerde artış olmuş, daha sonraki günlerde sürgünler yaşamamıştır. S4 ortamının ortalama değerlerinde ise hiç artış gözlenememiş, in vitro sürgünlerin ölmesine bağlı olarak ortalama değer sürekli azalmış ve 20. günde canlı sürgün kalmamıştır. En yüksek ortalama yaprak sayısı olan 13.80 adet/eksplant S8 ortamında 40. günde oluşurken, en düşük değer (3.87 adet/eksplant) ise $\mathrm{S} 1$ ortamında 60 . günde elde edilmiştir. Ortamlar bazında en yüksek ortalama yaprak sayısı (17.73 adet/eksplant) S9 ortamında, en düşük ortalama yaprak sayısı (1.35 adet/eksplant) da S4 ortamında elde edilmiştir. Kardeşlenme durumunu incelemek için yapılan 60 günlük gözlem sonucunda sağlanan verilerin istatistiki değerlendirmesine göre ortalama kardeşlenme sayıları ortam x zaman interaksiyonuna göre farklılık göstermektedir $(\mathrm{P}<0.05)$ ve bu farklılık istatistiksel açıdan önemlidir. Elde edilen ortalama değerler Çizelge 3.12 'de gösterilmiştir.

Çizelge 3.12. St. Julien A anacının besin ortamlarına göre ortalama kardeșlenme sayıları (adet/eksplant)

\begin{tabular}{|c|c|c|c|}
\hline \multirow{2}{*}{ Ortam } & \multicolumn{3}{|c|}{ Ortalama kardeşlenme sayısı (adet/eksplant) } \\
\cline { 2 - 4 } & 20.gün & $\mathbf{4 0 . g u ̈ n}$ & $\mathbf{6 0 . g u ̈ n}$ \\
\hline S 1 & $0.00 \mathrm{~h}$ & $0.00 \mathrm{~h}$ & $0.00 \mathrm{~h}$ \\
\hline S 2 & $0.53 \mathrm{efgh}$ & $0.93 \mathrm{efgh}$ & $2.00 \mathrm{def}$ \\
\hline S 3 & $1.53 \mathrm{ab}$ & $1.47 \mathrm{bc}$ & $1.60 \mathrm{bc}$ \\
\hline S 4 & $0.00 \mathrm{~h}$ & $0.00 \mathrm{~h}$ & $0.00 \mathrm{~h}$ \\
\hline S 5 & $0.13 \mathrm{gh}$ & $0.47 \mathrm{efgh}$ & $1.07 \mathrm{cde}$ \\
\hline S 6 & $0.40 \mathrm{efgh}$ & $1.00 \mathrm{cde}$ & $0.73 \mathrm{efg}$ \\
\hline S 7 & $0.00 \mathrm{~h}$ & $0.27 \mathrm{fgh}$ & $0.20 \mathrm{gh}$ \\
\hline S 8 & $0.13 \mathrm{gh}$ & $0.20 \mathrm{gh}$ & $0.00 \mathrm{~h}$ \\
\hline S 9 & $0.53 \mathrm{efgh}$ & $1.47 \mathrm{bcd}$ & $2.27 \mathrm{a}$ \\
\hline
\end{tabular}

$\mathrm{Bu}$ anacın besin ortamlarına göre ortalama kardeşlenme sayıları değerlendirildiğinde, S3 ortamında en yüksek kardeşlenme miktarının (1.15 adet/eksplant) elde edildiği; S9, S2, S6, S5, S7, S8 ortamlarının azalan değerlerle bu ortamın ardından geldiği, S4 ve S1 ortamlarında ise hiç kardeşlenme olmadığ tespit edilmiştir. Ortalama kardeşlenme sayısı, sürgün boyu ve yaprak sayısı S2, S5 ve S9 ortamlarında düzenli olarak artmıştır. S3 ortamında kardeşlenme durumu 20. güne kadar artmış, 40. günde azalmış, 60 . gün değerinde yeniden bir artış gözlenmiştir. S6, S7 ve S8 ortamlarında 40. güne kadar ortalama değerlerde artış olurken, sonrasında ortalama kardeşlenme sayılarında azalma görülmüştür. S8 ortamında 60. günde tüm sürgünler ölmüştür. S1 ve S4 ortamlarında kardeşlenme gerçekleşmediği için bu ortamlarda sürgün çoğalması sağlanamamıştır. En yüksek ortalama kardeşlenme sayısı, S9 ortamında 60. günde 2,27 adet/eksplant olurken, en düşük değer ( 0.20 adet/eksplant) S8 ve S7 ortamlarında 40 . ve 60 . günde elde edilmiştir. Tüm ortamlar açısından en büyük ortalama kardeşlenme sayısı deneme süresince düzenli bir artı̧̧ gösteremeyen S3 ortamında 1.15 adet/eksplant olmuş ve bu ortamı 1.07 adet/eksplant değeri ile S9 ortamı takip etmiştir. Sürgün çoğaltma aşamasında farklı sonuçlar alınan ortamların sürgün çoğalması ve gelişmesine etkilerini anlamak için ortalama sürgün boyu, yaprak sayısı ve kardeşlenme sayısı değerlerine bakıldığında sırasıyla S9, S3 ve S2 ortamları en iyi sonuçları verirken; S4, S1 ve S7 ortamları ise en az başarı gösteren ortamlar olmuştur. Bu gelişme durumlarına Şekil 3.4 'te örnek görüntüler verilmiştir. 

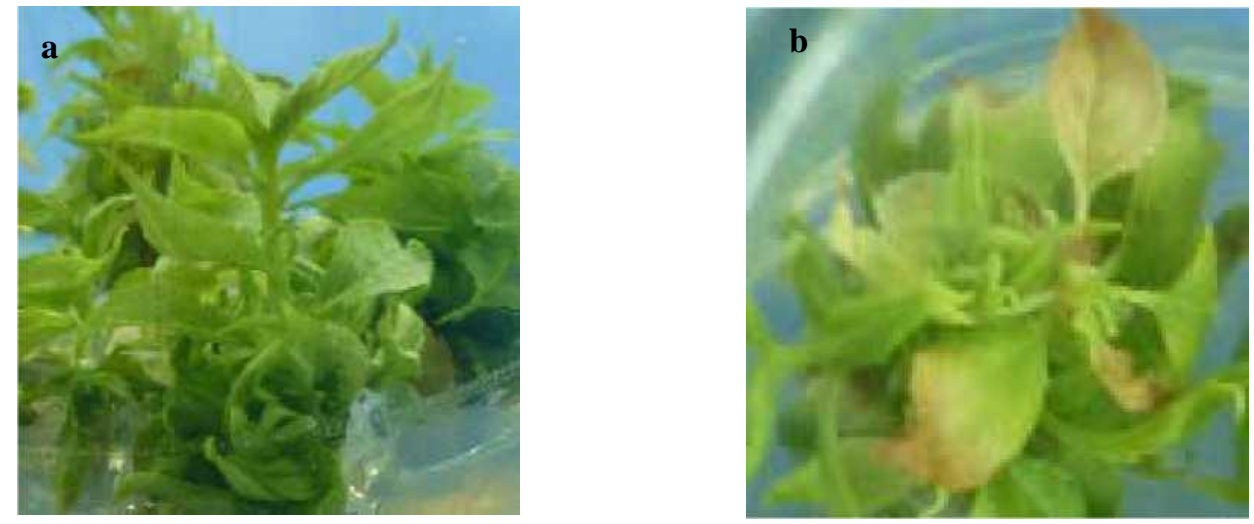

Șekil 3.4. St. Julien A anacının S9 (a) ve S4 (b) ortamlarında 5. hafta sonundaki gelişme durumu

\subsection{Köklendirme Aşaması}

Marianna GF 8/1, Myrobolan B ve St. Julien A klon anaçlarına ait mikro sürgünlerin köklendirilmesi amacıyla bitki büyüme düzenleyici içeriği farklı $8 \mathrm{MS}$ (Murashige and Skoog) besin ortamı kullanılmıştır (Çizelge 3.13). Myrobolan 29-C anacında yeterli mikroçoğalma sağlanamadığı için bu anaç köklendirme aşamasına alınmamıştır. Ortalama değerlere göre hesaplanan ortalama köklenme oranları Çizelge 3.13 'te verilmiştir.

Cizelge 3.13. Besin ortamlarına göre anaçların ortalama köklenme oranları (\%)

\begin{tabular}{|c|c|c|c|c|}
\hline \multirow{2}{*}{ Ortam } & \multicolumn{4}{|c|}{ Anaç } \\
\cline { 2 - 5 } & Marianna GF 8/1 & $\begin{array}{c}\text { Myrobolan } \\
\text { B }\end{array}$ & $\begin{array}{c}\text { St. Julien } \\
\text { A }\end{array}$ & Ortalama \\
\hline K 1 & 27 & 40 & 33 & $33.3 \mathrm{~cd}$ \\
\hline K 2 & 47 & 60 & 53 & $53.3 \mathrm{abc}$ \\
\hline K 3 & 33 & 33 & 40 & $35.3 \mathrm{bcd}$ \\
\hline K 4 & 67 & 60 & 53 & $60.0 \mathrm{abc}$ \\
\hline K 5 & 27 & 27 & 27 & $27.0 \mathrm{~d}$ \\
\hline K 6 & 40 & 53 & 53 & $48.6 \mathrm{bcd}$ \\
\hline K 7 & 73 & 73 & 73 & $73.0 \mathrm{a}$ \\
\hline K 8 & 73 & 67 & 67 & $69.0 \mathrm{ab}$ \\
\hline
\end{tabular}

Köklenme oranları bakımından ortamlar arasındaki farklılık istatistiksel olarak önemli bulunurken $(\mathrm{P}<0.05)$, anaçlar arasındaki farklılık ve ortam $\mathrm{x}$ anaç interaksiyonu önemsiz bulunmuştur. Tüm anaçların ortalama köklenme değerleri esas alındığında $\mathrm{K} 7$ ortamında en yüksek köklenme oranı (\% 73) elde edilmiştir. Bu ortamı K8 (\% 67), K4 (\% 60) ve K2 (\% 53) ortamları izlemiştir. Çalışmada K5 ortamı ise en düşük köklenme oranına (\% 27) sahip olmuştur. Bu oranı sırasıyla $\% 33, \% 40$ ve $\% 53$ ile K1, K3 ve K6 ortamları takip etmiştir. Anaçların ortamlara göre ortalama köklenme oranları değerlendirildiğinde Marianna GF 8/1 ve Myrobolan B anaçlarının köklenme oranları \% 27 ile \% 73 değerleri arasında değişirken, St. Julien A anacının ise \% 33 ile \% 73 değerleri arasında değişmiştir. Her üç anaç da en yüksek köklenme oranına (\% 73), K7 (1/2 MS + $\left.2 \mathrm{mg} \mathrm{L}^{-1} \mathrm{IBA}\right)$ ortamında ulaşmıştır. Ayrıca Marianna GF 8/1 anac1 K8 ortamında en yüksek köklenme oranı olan \%73'e ulaşmıştır. K7 ortamından sonra köklenmede en başarılı ikinci ortam \% 67 köklenme oranına sahip olan K8 (1/2 MS + $\left.2 \mathrm{mg} \mathrm{L}^{-1} \mathrm{NAA}\right)$ ortamıdır.

Köklenme ortamlarına dikilen mikro sürgünlerde ilk kök oluşumları 5. günde görülmüştür. Köklenmeler sırasıyla 7., 10., 12. ve 15. günlerde meydana gelmiştir. En son köklenmeler 20. günde olmuştur. 20. 
günden sonra köklenme meydana gelmemiş, köklenmeyen bitkiler ya kurumuş ya da aynı gelişme seyrini sürdürmüştür. Çalışmada K7 ortamında köklendirilen Marianna GF 8/1, Myrobolan B ve St. Julien A anaçlarının köklü bitkicikleri Şekil 3.5 'de gösterilmiştir.
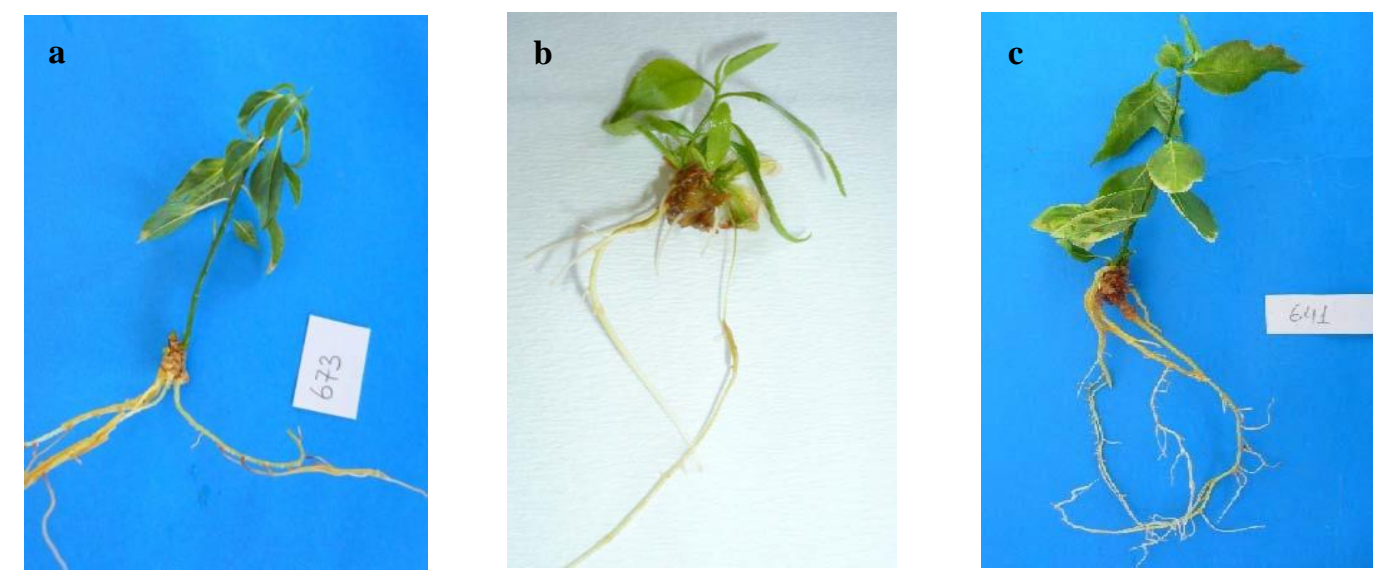

Sekil 3.5. K7 ortamında köklenen Marianna GF 8/1 (a), Myrobolan B (b) ve St. Julien A (c) anaçlar1

\section{Tartışma ve Sonuç}

Bu çalışmada, Marianna GF 8/1, Myrobolan B, Myrobolan 29-C ve St. Julien A klon anaçlarının doku kültürü ile optimum çoğaltma koşullarının belirlenmesi için sürgün ucu eksplantları, bitki büyüme düzenleyici içerikleri farklı olan 9 MS besin ortamında kültüre alınmıştır. Bu besin ortamlarından sürgün çoğaltma aşamasında alınan sonuçlar farklı olmuştur. Marianna GF 8/1 anacında sürgün çoğalması bakımından en başarılı ortamlar S2, S7, S9, S3 ve S8 olmuştur. Bu ortamları, S1 ortamı takip etmiştir. Başarısı daha düşük olan ortamlar ise S5, S4 ve S6 ortamları olmuştur. Myrobolan B anacı için en başarılı olan ortamlar S2, S5, S6 ve S9' dur. Buna karş1lık S4, S3, S7 ve S8 ortamları ise en az başar1 gösteren ortamlardır. St. Julien A anacı için ortalama sürgün boyu ve yaprak sayısı değerlerine bakıldığında sırasıyla S9, S3 ve S2 ortamları en iyi sonuçları verirken; S4, S1 ve S7 ortamları ise en az başar1 sağlayanlar olmuştur. Kardeşlenme değerlerini incelediğimizde S3, S9 ve S2 ortamlarında en fazla; S4, $\mathrm{S} 1, \mathrm{~S} 8$ ve S7 ortamlarında ise en az miktarda kardeşlenme olduğu görülmektedir. S4 ve S1 ortamlarında kardeşlenme olmaması bu iki ortamda St. Julien A anacının çoğalmadığını göstermektedir. S3 ortamında ise en yüksek çoğalma miktarı (1,15 adet/eksplant) ortaya çıkmıştır. Bu durum, anaç için başarılı olan ortamlarda düzenli bir sürgün çoğalması meydana geldiğini ifade etmektedir. St. Julien A anacı için denenen ortamlardan S9, S3, S2 ve S5 ortamlarında başarılı sürgün çoğalmas1 gerçekleşmiş; S4, S1, S7 ve S8 ortamlarında ise başarılı bir çoğalma sağlanamamıştır. Myrobolan 29-C anacının sürgün boyu, yaprak sayısı ve kardeşlenme durumu S5 ortamında deneme boyunca artış göstermiştir. S1 ortamında ise sürgün gelişmesinin gerilediği göze çarpmıştır. Buna göre Myrobolan 29-C anac1 için S5 ortamı, S1 ortamından daha iyi sonuç vermiştir.

S1 (1 mg L $\left.{ }^{-1} \mathrm{BAP}+0.1 \mathrm{mg} \mathrm{L}^{-1} \mathrm{NAA}\right)$ ortamı, Marianna GF 8/1 ve Myrobolan B anaçlarının sürgün çoğalmasında iyi sonuç verirken, St. Julien A ve Myrobolan 29-C anaçlarında çok az sürgün verimi sağlamıştır. S1 ortamının iyi sonuç verdiğini destekleyen Sauer (1985) tarafından kiraz anacı Mazzard üzerinde yapılan bir araştırmada da genç sürgünlerin tepe tomurcuklarına ait meristemler $2 \mathrm{mg} \mathrm{L}^{-1} \mathrm{BAP}$ ve $0,1 \mathrm{mg} \mathrm{L}^{-1} \mathrm{NAA}$ içeren MS besin ortamında kültüre alınmış ve yan sürgünlerin gelişmesi sağlanmıştır. Heimanns Rubinweichsel vişne çeşidinde Özzambak ve Hepaksoy (1997a) tarafından yapılan bir in vitro sürgün çoğaltma çalışmasında da benzer bir sonuç alınmış olup, $0.5 \mathrm{mg} \mathrm{L}^{-1} \mathrm{BAP}$ ve $0.1 \mathrm{mg} \mathrm{L}^{-1} \mathrm{NAA}$ eklenmiş MS besin ortamında en fazla sürgün çoğalması sağlanmıştır. Bu çalışmada $1.0-1.5 \mathrm{mg} \mathrm{L}^{-1}$ BAP ilave edilen MS ortamının ideal alt kültür ortamı olduğu belirlenmiştir. BAP yerine aynı miktarda IAA, IBA ve NAA uygulandığında da benzer sonuçlar alınmıştır. Prunus persica ile Prunus amygdalus melezi olan ve şeftali'ye anaç olarak kullanılan PR 204/84 klon anacı üzerinde yapılan bir çalışma da çalışmamızı desteklemektedir. Fotopolous ve Sotiropolous, (2005) tarafindan yapılan bu çalışmada, en fazla sürgün uzaması, $8.0 \mu \mathrm{M}$ BAP $+5.0 \mu \mathrm{M}$ NAA ve $4.0 \mu \mathrm{M}$ BAP $+5.0 \mu \mathrm{M}$ IBA içeren ortamlarda gerçekleşmiştir. S2 $\left(1 \mathrm{mg} \mathrm{L}^{-1} \mathrm{BAP}+0.1 \mathrm{mg} \mathrm{L}^{-1} \mathrm{NAA}+0.1 \mathrm{mg} \mathrm{L}^{-1} \mathrm{GA} 3\right)$ ve S $3\left(1 \mathrm{mg} \mathrm{L}^{-1} \mathrm{BAP}+0.1 \mathrm{mg}\right.$ 
$\mathrm{L}^{-1} \mathrm{IAA}+0.1 \mathrm{mg} \mathrm{L}^{-1} \mathrm{GA} 3$ ) ortamlar1, sitokinin (BAP), oksin (NAA ve IAA) ve gibberellin (GA3) grubu olmak üzere tüm gruplardan bitki büyüme düzenleyicileri içeren ortamlardır. Çalışmamızda, farklı oksin kullanımının çoğalmayı nasıl etkilediğini incelemek için S2 ortamından farklı olarak içeriğinde IAA bulunan S3 ortamı denenmiştir. Alınan sonuçlara göre S2 ve S3 ortamları Marianna GF 8/1, ve St. Julien A anaçlarında en iyi sürgün çoğalmasını sağlayan ortamlar arasında yer almış, Myrobolan B anacı ise sadece S2 ortamında iyi çoğalmıştır. Marianna GF 8/1 ve Myrobolan B anaçları NAA varlığında yani S2 ortamında daha iyi sonuç vermiştir. Benzer şekilde Ruzic ve ark. (1998) S2 ortamıyla aynı bitki büyüme düzenleyici içeriğinde olan MS ortamında, kiraz anaçlarının en iyi çoğalmayı sağladığını vurgulamışlardır. Yine S2 ortamının iyi sonuç verdiğini ortaya koyan Ruzic ve ark. (2000) tarafından Gisela 5 anacında yapılan bir başka denemede, MS makro elementleri sırasıyla iki katı kuvvetinde, $1 / 2$ ve $1 / 4$ kuvvetinde alınarak, $4.4 \mu \mathrm{M} \mathrm{BA}+0.5 \mu \mathrm{M}$ NAA $+0.3 \mu \mathrm{M}$ GA3 ilave edilmiş ve pH 5.78'e ayarlanmıştır. $\mathrm{Bu}$ ortamların sürgün çoğalması ve büyümesi üzerine etkisi incelendiğinde makro elementlerin iki katı kuvvette kullanıldığı ortamda en iyi çoğalma ve büyümenin gerçekleştiği saptanmıştır.

Çalışmamıza paralel olarak Arıcı (2008)'nın sert çekirdekli meyve türleri için kullanılan Maxma-14 ve GN anaçlarının sürgün ucu ve yan sürgünleri ile çoğaltma olanaklarını araştırdığı çalışmada, Maxma-14 anac1 için $2.0 \mathrm{mg} \mathrm{L}^{-1} \mathrm{BAP}+0.2 \mathrm{mg} \mathrm{L}^{-1} \mathrm{NAA}+0.5 \mathrm{mg} \mathrm{L}^{-1} \mathrm{GA} 3, \mathrm{GN}$ anacı için $1.0 \mathrm{mg} \mathrm{L}^{-1} \mathrm{BAP}+0.02$ mg L ${ }^{-1} \mathrm{NAA}+0.5 \mathrm{mg} \mathrm{L}^{-1} \mathrm{GA} 3$ içeren ortamlarda başarılı sürgün çoğalmasının olduğu bildirilmiştir. S4 $\left(2 \mathrm{mg} \mathrm{L}^{-1} \mathrm{BAP}+0.1 \mathrm{mg} \mathrm{L}^{-1} \mathrm{IBA}+0.25 \mathrm{mg} \mathrm{L}^{-1} \mathrm{GA} 3\right)$ ve S5 (1 mg L $\mathrm{m}^{-1} \mathrm{BAP}+0.5 \mathrm{mg} \mathrm{L}^{-1} \mathrm{IBA}+0.25 \mathrm{mg}$ $\left.\mathrm{L}^{-1} \mathrm{GA} 3\right)$ ortamları da üç ana gruptan bitki büyüme düzenleyicileri içermektedir; ancak, S2 ve S3 ortamlarından farklı olarak bunlar IBA içermektedir. Yaptığımız denemede Marianna GF 8/1 anacının S4 ve S5 ortamlarında, Myrobolan B ve St. Julien A anaçlarının ise S4 ortamında iyi çoğalma sağlayamadığı ve camsılaşma oluşumuna eğilimli hale geldiği görülmüştür. S4 ortamında BAP seviyesinin yüksek $\left(2 \mathrm{mg} \mathrm{L}^{-1}\right)$ olması bu anaçların sürgün gelişimini olumsuz etkilemiştir. Bu bulguya paralel olarak Gürel ve Gülşen (1998) adlı araştırıcıların yaptığı çalışmada da yüksek BAP (2 veya 3 mg $\mathrm{L}^{-1}$ ) konsantrasyonunun, sürgünlerde camsılaşma ve canlılık azalmasına neden olduğu bildirilmiştir. Buna karşılık Myrobolan B, St. Julien A ve Myrobolan 29- C anaçları S5 ortamında başarılı olarak çoğaltılmıştır. Bu iki anacın $1 \mathrm{mg} \mathrm{L}^{-1} \mathrm{BAP}$ uygulandığında daha iyi sürgün oluşturduğu ve çoğaldığ belirlenmiştir. Hepaksoy ve Tanrısever (2004) de Gisela 5 ve Gisela 5 anaçlarında denedikleri S5 ortamı ile içerikli MS ortamında başarılı sürgün çoğalmasının sağlandığını ifade etmişlerdir. S6 ve S7 ortamlarında ise sürgün çoğalmasında PG'ün etkisi araştırılmıştır. S7 (4.4 $\mu \mathrm{M}$ BAP + 0.49 $\mu \mathrm{M}$ IBA + $0.29 \mu \mathrm{M} \mathrm{GA} 3+1 \mathrm{mM}$ PG) ortamı PG (Floroglisinol) içermektedir. S7 ortamında Marianna GF 8/1 anacının iyi sürgün gelişimi sağladığı görülmüştür. Myrobolan B ve St. Julien A anaçları ise S7 ortamında iyi çoğalma sağlayamamıştır. Bunun yanında S7 ortamı ile aynı bitki büyüme düzenleyici içeriğine sahip olan ve PG içermeyen S5 $(4.4 \mu \mathrm{M}$ BAP + 0.49 $\mu \mathrm{M}$ IBA + 0.29 $\mu \mathrm{M}$ GA3) ortamında ise Myrobolan B ve St. Julien A anaçları iyi çoğalma sağlarken, Marianna GF 8/1'de daha düşük miktarda sürgün çoğalması sağlamıştır. Eksplant dokusunun besin ortamına salgıladığı fenolik maddeler, ortamda kararmaya neden olup eksplant gelişimini engellemektedir. Pontikis ve Melas (1986), fenolik maddelerin bu etkisini azaltmak veya ortadan kaldırmak için besin ortamına floroglisinol eklenmesini tavsiye etmektedir. Çalışmamızda PG uygulaması, bazı anaçlarda sürgün çoğalmasını arttırırken bazılarında azaltmıştır. PG uygulamasını destekleyen bir çalışmada, F 12/1 (Prunus avium) ve Colt (P. avium x P. pseudocerasus) kiraz anaçlarında sürgün ucu yöntemi ile çalışan Hammatt ve Grant (1993), besin ortamının $2.2 \mu \mathrm{M}$ BA ve $1.0 \mu \mathrm{M}$ floroglisinol (PG) içermesi, 5.5 veya $6.5 \mathrm{~g} \mathrm{~L}^{-1}$ agar ilave edilmesi ve pH'sının 5.0 olması durumunda sürgün çoğalmasının arttığını tespit etmişlerdir. S6 ortamıyla aynı bitki büyüme düzenleyicileri içeren bir ortamın kullanıldığı başka çalışmada da Espinosa ve ark. (2006) tarafindan Kara Kiraz (Prunus serotina) üzerinde sürgün çoğaltma denemesi yapılmıştır. MS besin ortamına $4.44 \mu \mathrm{M}$ BA, $0.49 \mu \mathrm{M}$ IBA ve $0.29 \mu \mathrm{M}$ GA3 ilave edilerek boğumların kültüre alındığ çalışmada sürgün proliferasyonu sağlandığı bildirilmiştir.

S8 (1 mg L $\mathrm{m}^{-1} \mathrm{BAP}$ pH 5.6) ve $\mathrm{S} 9$ (1 $\mathrm{mg} \mathrm{L}^{-1} \mathrm{BAP} \mathrm{pH}$ 6.2) ortamları içerikleri aynı sadece pH dereceleri birbirinden farklı iki ortamdır. Farklı pH derecelerinin sürgün çoğalmasına etkisini araştırmak amacıyla S9 ortamına alternatif olarak S8 ortamı denenmiştir. Bu iki ortam karşılaştırıldığında pH nın yüksek olması (S9) durumunda çoğalmada artışın sağlandığı gözlenmiştir. Marianna GF 8/1, Myrobolan B ve St. Julien A anaçlarında yüksek pH derecesi sürgün çoğalmasını arttırmıştır. S8 ortamında ise Marianna GF 8/1 anacı için orta düzeyde sürgün çoğalması elde edilirken; Myrobolan B ve St. Julien A anaçları için az miktarda sürgün çoğalması gerçekleşmiştir. Denememizdeki S8 ortamına benzer olarak Gürel ve Gülşen (1998) tarafından Texas ve Nonpareil badem (Amygdalus communis L.) çeşitleri üzerinde yapılan

80 | P a g e

www.iiste.org 
sürgün ucu çalışmasında farklı sakkaroz, agar ve $\mathrm{pH}$ düzeylerinin sürgün çoğalması ve gelişmesine etkisi incelenmiştir. İlk dikim aşamasında sakkaroz dozu \% 5-6 ve pH ayarı 5.5 olduğunda çoğalma sağlanmış ve en iyi sürgün gelişimi olmuştur. Alt kültüre alma aşamasında yine \% 5-6 sakkaroz miktarı ile pH düzeyi 5.5 olan ortamlarda sürgün gelişmesinin en iyi olduğu görülmüştür. Damil, Edabriz, Gisela 5 ve MaxMa kiraz anaçları üzerinde S9 ortamını destekleyen bir çalışma yapılmıştır. Besin ortamına eklenen değişik katılaştırıcı maddelerin ve farklı $\mathrm{pH}$ düzeylerinin sürgün çoğalmasına, sürgün uzunluk ve ağırlığına etkilerinin incelendiği bu çalışmada en uygun $\mathrm{pH}$ düzeyinin 6.2 ve en iyi sonucu veren katılaştırıcı maddenin agar olduğu belirlenmiştir (Aka-Kaçar ve ark., 2001). Sürgün çoğaltma aşamasında yapılan istatistiki değerlendirmeye göre anaçların denenen besin ortamlarındaki kardeşlenme miktarlarının az olduğu görülmektedir. Deneme sırasında bazı mikro sürgünlerin uç kısımlarında kurumaların meydana gelmesi ve bazı sürgünlerin de tamamen ölmesi nedeniyle 60 gün sonunda hiç canlı sürgünün kalmadığı ortamlarda kardeşlenme miktarları düşük olmuştur. Bu durum dikkate alındığında, istatistiksel analizlere göre farklı ortamlar başarılı olarak ön plana çıkmış olsa da deneme süresince yapılan gözlemlere göre genel olarak tüm anaçlar için en iyi sürgün çoğalmasının gerçekleştiği ortam $1 \mathrm{mg} \mathrm{L}^{-1} \mathrm{BAP}+0.5 \mathrm{mg} \mathrm{L}^{-1} \mathrm{IBA}+0.25 \mathrm{mg} \mathrm{L}^{-1} \mathrm{GA} 3$ bitki büyüme düzenleyici içeriğine sahip olan S5 ortamıdır.

Çalışmanın köklendirme aşamasında da besin ortamlarından farklı sonuçlar alınmıştır. Bunların içinde en başarılı olan ortam oksin olarak $2 \mathrm{mg} \mathrm{L}^{-1}$ IBA içeren ve $1 / 2$ kuvvette MS uygulanan $\mathrm{K} 7$ ortamı olmuştur. Denemede ikinci başarıı olan ortam ise yine yarı kuvvette MS besin ortamına IBA yerine aynı miktarda NAA ilave edilen K8 ortamıdır. Al-Sabbagh ve ark. (1999) tarafindan yapılan benzer çalışmada da IBA veya NAA içeren ortamlarda başarılı köklenmenin gerçekleştiği doğrulanmaktadır. Bu araştırıcılar katı ve sıvı MS ortamına $0.49 \mu \mathrm{M}$ NAA veya $0.49-2.45 \mu \mathrm{M}$ IBA ilavesiyle 4 hafta sonunda köklenmenin gerçekleştĭgini bildirmiştir. Epstein ve ark. (1993) ise farklı köklenme özelliği gösteren kiraz çeşitleri üzerinde yaptıkları bir araştırmada aseptik koşullarda IBA'nın taşınımı ve metabolizmasını incelemişlerdir. Çalışmalarında oksine en iyi yanııın alındığı 2., 3., 4. ve 5. günleri köklenme periyodu olarak tanımlamış ve kolay köklenen çeşitlerin sürgünlerini köklenme ortamına aldıktan 7 gün sonra ilk kök oluşumunun görüldüğ̈ünü bildirmișlerdir. Paul ve Feucht (1985) tarafindan Hedelfinger ve Sam kiraz çeşitleri üzerinde yapılan köklendirme denemesinde de agarla katılaştırılmış modifiye MS ortamı kullanılarak IBA, NAA ve IAA'nın köklenme üzerine etkisi incelenmiştir. Bizim bulgularımıza benzer olarak köklenme üzerinde en etkili oksinin IBA olduğu saptanmıştır. Zor köklendiği bilinen bu iki kiraz çeşidi üzerinde yapılan çalışmada ortalama $\% 90$ oranında köklenme sağlanmıştır. Sam çeşidi tüm IBA konsantrasyonlarında $\left(0.5,0.75\right.$ ve $\left.1.0 \mathrm{mg} \mathrm{L}^{-1}\right)$ yüksek oranda köklenirken, Hedelfinger çeşidinde $1.0 \mathrm{mg}$ $\mathrm{L}^{-1}$ IBA ile en yüksek köklenme oranı elde edilmiştir. Snir (1982)'in kirazda yaptığı köklendirme çalışmasında da in vitro sürgünlerin, $1 \mathrm{mg} \mathrm{L}^{-1} \mathrm{IBA}, \% 2$ sakkaroz ve $\% 0.7$ agar içeren, $\mathrm{pH}$ 's1 5.3 olan $1 / 2$ oranında seyreltilmiş MS ortamında en fazla köklendikleri tespit edilmiştir. Pevalek-Kozlina ve Jelaska (1987) tarafindan yabani kiraz anacında yapılan çalışmada ise in vitro sürgünlerden $4.9 \mu \mathrm{M}$ IBA içeren besin ortamında, yan sürgünlerden ise $2.46 \mu \mathrm{M}$ IBA çözeltisine batırıldıktan sonra en iyi köklenmenin oluştuğu ifade edilmiştir. Bu araştırıcıların denediği ortam bizim denememizde $\% 45$ oranında kök oluşumu sağlamıştır. Özzambak ve Schmidt (1991) adlı araştırıcılar da kirazda yaptıkları çalışmada Early Burlat ve Viola çeşitleri ile F 12/1 ve 209/1 anaçlarının in vitro sürgünlerinin $1,0 \mathrm{mg} \mathrm{L}^{-1}$ IBA içeren $1 / 2$ kuvvette MS ortamında iyi köklendiğini rapor etmişlerdir. Çalışmamızda en iyi sonucu veren K5 ortamı bu ortamdan farklı olarak $1.0 \mathrm{mg} \mathrm{L}^{-1}$ IBA yerine $2 \mathrm{mg} \mathrm{L}^{-1}$ IBA içermektedir. Özzambak ve Hepaksoy (1997b) tarafindan yapılan çalışmada ise kiraz sürgünleri 5.5, 11.0, 16.5 ve $22.0 \mu \mathrm{M}$ IAA, IBA ve NAA eklenen 1/2 MS besin ortamında köklendirilmiștir. Calıșma sonunda belirtilen miktarlardaki bitki büyüme düzenleyicilerin kullanımıyla iyi köklenme sağlandığı, ancak; bizim denememizden farklı olarak kök rengi, şekli, kalınlığı ve kallus oluşum oranının IAA varlığında diğerlerine göre daha iyi sonuç verdiğini rapor etmişlerdir. Çalışmamızda $2 \mathrm{mg} \mathrm{L}^{-1} \mathrm{NAA}$ içeren $\mathrm{K} 8$ ortamında $\% 69$ oranında kök oluşumu sağlanmıştır. Demiral ve Ülger (2008) tarafindan Gisela 5 kiraz anacı üzerinde yapılan benzer bir köklendirme çalışmasında MS ortamına $0,1,2,4$ ve $6 \mathrm{mg} \mathrm{L}^{-1} \mathrm{NAA}$ ilave edilmiş ve en iyi köklenme $\% 92.88$ oranı ile $6 \mathrm{mg} \mathrm{L}^{-1} \mathrm{NAA}$ uygulamasından elde edilmiştir.

Denememizde standart içeriğinde $0.1 \mathrm{mg} \mathrm{L}^{-1}$ Thiamin bulunan MS besin ortamına ilave olarak $1.4 \mathrm{mg} \mathrm{L}^{-}$ ${ }^{1}$ daha Thiamin eklenmiş K2 ortamı tüm anaçlar için K1 ortamından daha başarılı sonuç vererek \%53.3 köklenme oranına ulaşmıştır. K1 ortamında ise köklenme oranı \%33.3 olmuştur. Besin ortamına Thiamin eklenmesi mikro sürgünlerin köklenmesini olumlu etkilemektedir. Bizim denememizdeki K2 ortamına benzer bir ortam içeriği deneyen Kamali ve ark. (2006) LS ortamına $0.3 \mathrm{mg} \mathrm{L}^{-1} \mathrm{NAA}$ ve $1.6 \mathrm{mg} \mathrm{L}^{-1}$ Thiamin eklendiğinde GF 677 ve farklı badem anaçlarının \%80 oranında kök meydana getirdiğini

81 | $P$ a g e 
bildirmektedir. Çalş̧mamızda $0.3 \mathrm{mg} \mathrm{L}^{-1}$ Thiamin ilave edilen K1 ortamında (\%33.3) daha az oranda köklü bitkicik elde edilmiştir. Esmenjaud ve ark. (1993) tarafından Myrobolan erikleri üzerinde yapılan bir çalışmada ise K1 ortamına benzer içerikli bir ortamda Thiamin miktarının köklenmeye etkisi araştırılmıştır. Bizim bulgularımızdan farklı bir sonuca ulaşan bu araştırıcılar denemede ilk olarak 0.4 $\mathrm{mg} \mathrm{L}^{-1}$ Thiamin ve $0.5 \mathrm{mg} \mathrm{L}^{-1}$ IBA ilave edilen, ikinci olarak da sadece $0.4 \mathrm{mg} \mathrm{L}^{-1}$ Thiamin eklenen MS ortamlarında başarılı kök oluşumunun sağlandığını bildirmişlerdir. K6 ortamından farklı olarak 283.72 $\mathrm{mg} \mathrm{L}^{-1} \mathrm{PG}$ içeren $\mathrm{K} 4$ ortamı kök oluşumunda daha iyi sonuç vermiştir. Ortama PG (Floriglisinol) ilave edilmesi köklenme oranını arttırmaktadır. Ne Plus Ultra ve Nonpareil badem (Prunus dulcis Mill.) çeşitlerinin köklenme durumunun araştırıldı̆̆ı bir deneme de bu bulguyu desteklemektedir. Mikro sürgünlerde kök oluşumu için uygun oksinin belirlenmesi amacıyla inkübasyon safhasında IBA ve NAA'nın farklı konsantrasyonlarının uygulandığı çalışmada ayrıca köklenme üzerinde PG etkisi de araştırılmıştır. En başarııı köklenme 1,0 mM IBA ilaveli \%0.6 agar içeren MS besin ortamında 12 saat inkübe edildikten sonra iki hafta $100.0 \mathrm{mM} \mathrm{PG}$ içeren oksinsiz ortamda tutulan kültürlerde sağlanmıştır (Ainsley ve ark., 2001).

Çalışmamızda ortamlar bakımından ortalama köklenme oranları \%33.3 ile \%73 arasında değişmiştir. En fazla köklenme \%73 ile K7 ortamında olurken, bu ortamı K8 (\%69), K4 (\%60), K2 (\%53.3), K6 (\%48.6), K3 (\%35.3), K1 (\%33.3) ortamları izlemiş ve en az köklenme ise \%27 ile K5 ortamında elde edilmiş̧ir. Anaç bazında en yüksek köklenme oranı olan \%73, K 7 ve K8 ortamlarında Marianna GF 8/1 ile K7 ortamında Myrobolan B ve St. Julien A anaçlarında görülürken, en düşük köklenme oranı \%27 ise K1 ve K5 ortamlarında Marianna GF 8/1 ile K5 ortamında Myrobolan B ve St. Julien A anaçlarına ait olmuştur. Anaçların ortamlara göre en iyi köklenme oranları incelendiğinde Marianna GF 8/1 anacı K 7 ve K 8 ortamlarında $\% 73$ oranında, Myrobolan B anacı K 7 ortamında $\% 73$ oranında, St. Julien A anacı K 7 ortamında $\% 73$ oranında köklenme sağlamıştır. Denememizin sonunda elde edilen in vitro bitkicikler viyollere aktarılmıştır. Viyoller, sulama işleminin ardından üzerleri naylon örtü ile kapatılarak iklim odasına konulmuştur. İklim odasında sadece sıcaklık kontrolü yapılmıştır. Deneme mikroçoğaltımın son aşaması olan dış koşullara alıştırma safhasına kadar getirilmiş ve burada sonlandırılmıştır.

\section{Bilgilendirme}

Bu çallş̧ma Mine Akşsehirli Pakyürek'in doktora tezinden üretilmiş olup, Ege Üniversitesi Bilimsel Araştırma Projeleri Koordinatörlüğ̈̈ tarafindan 07-ZRF-002 nolu proje ile desteklenmiştir.

\section{References}

Ainsley, P.J., Collins, G.G. \& Sedgley, M. (2001). In vitro rooting of Almond (Prunus dulcis Mill.). In Vitro Cell Dev. Biol. Plant. 37, 778-785.

Aka-Kaçar, Y., Yılmaz, N., Yalçın-Mendi, Y., Küden, A. \& Çetiner, S. (2001). In vitro besi ortamında kullanılan değişik katılaştırıcı maddelerin ve farklı $\mathrm{pH}$ düzeylerinin bazı kiraz (Prunus avium L.) anaçlarının çoğaltılması üzerine etkileri. I. Sert Çekirdekli Meyveler Sempozyumu. 25-28 Eylül 2001, Yalova, 161-166.

Anonim (1969) Research and training centers for the production, processing and marketing of fruit and vegetables. Turkey. UNDP/ FAO Technical Report 1, Rome. 150 p.

Anonim (2008b). http://www.cevizfidan.com/seftali.htm (Erişim Tarihi: 2 Nisan 2009)

Anonim (2008c). http://www.bahcesel.com/content/view/ 914/ 3188. (Erişim Tarihi: 5 Nisan 2009)

Arıcı, Ş. E. (2008). Bazı Sert Çekirdekli Meyve Anaçlarının Doku Kültürü ile Çoğaltılması. Süleyman Demirel Üniversitesi Ziraat Fakültesi Dergisi, 3(1), 19-23.

Büyükyılmaz, M. \& Öz, F. (1994). Yaprağını döken meyve türlerinde kullanılan anaçlar. Atatürk Bahçe Kültürleri Araştırma Enstitüsü, Yayın No: 70. 
Debergh, P.C. \& Read, P. E. (1993). Micropropagation. In: Debergh PC, Zimmerman RH (eds), Micropropagation-Technology and Application. pp. 1-15, Kluwer Academic Publishers, Dordrecht, Hollanda.

Demiral, S. \& Ülger, S. (2008). Gisela 5 Kiraz Anacının Doku Kültürü ile Çoğaltılması Üzerine Bir Araştırma. Akdeniz Üniversitesi Ziraat Fakültesi Dergisi. 21(1), 117-121.

Ertürk, U., Sivritepe, N., Yerlikaya, C., Bor, M., Ozdemir, F. \& Turkan, I. (2007). Responses of the cherry rootstock to salinity in vitro. Biologia Plantarum. 51 (3), 597-600.

Esmenjaud, D., Minot, J.C., Voisin, R., Salesses, G., Poupet, R. and Onesto, J.P. (1993). Assessment of a method using plantlets grown previously in vitro for studying resistance of Prunus cerasifera Ehr. (Myrobolan Plum) to Meloidogyne spp. Nematropica, 23(1), 41-48.

Espinosa, A.C., Pijut, P.M., \& Michler, C.H. (2006). Adventitious shoot regeneration of Prunus serotina in vitro cultures. Hortscience, 41(1), 193 201.

Fotopolous, S. \& Sotiropoulos, T.E. (2005). In vitro rooting of PR 204/84 (Prunus persica x P. Amygdalus) rootstock: axillary shoot production and rhizogenesis. New Zealand Journal of Crop and Horticulture Science, 33, 75-79.

George, E.F., Hall, M.A. \& De Klerk G.J. (2008). Plant Propagation By Tissue Culture 3rd Edition, Volume1. The Background, Chapter 1, p: 1-28, Springer.

Gürel, S. \& Gülşen Y. (1998). The Effects of Different Sucrose, Agar and pH Levels on In Vitro Shoot Production of Almond (Amygdalus communis L.). Turkish Journal of Botany, 22, 363-373.

Hammatt, N. \& Grant, N.J. (1997). Micropropagation of mature British wild cherry. Plant Cell, Tissue and Organ Culture, 47: 103-110.

Hartmann, H.T. \& Kester, D.E. (1983). Plant propagation principles and practices. 3 rd Ed. Printice Hall, Inc. London, 727 p.

Hepaksoy, S. (2004). Bazı kiraz anaçlarının mikroçoğaltımı üzerinde araştırmaları. Gelişme ve Çoğalma. Ege Üniversitesi Ziraat Fakültesi Dergisi, 41(3), 11-22.

Hepaksoy, S. \& Tanrısever, A. (2004). Bazı kiraz anaçlarının mikroçoğaltımı üzerinde araştırmalar II. Köklenme ve dış koşullara alıştırma. Ege Üniversitesi Ziraat Fakültesi Dergisi, 41(3), 23-34.

Kamali, K., Majidi, E., \& Zarghami, R. (2001). Micropropagation of GF-677 rootstocks (Prunus amygdalus x $P$. persica). Chaiers Options Mediterraneennes. 175-177.

Kamali, K., Majidi, E., Zarghami, R. \& Arvin, M.J. (2006). Differences in micropropagation of vegetative rootstock (GF 677) and other almond seed genotypes. ISHS Acta Hort. 726.

Karvar, S. \& Gülşen, Y. (1990). Bademin (Prunus amygdalus Batsch.) in vitro vejetatif çoğaltımında besin ortamı içeriğinin sürgün verimine etkileri. Ankara Üniversitesi, Fen Bilimleri Enstitüsü. Yüksek Lisans Tezi. Ankara.

Mansuroglu, S. \& Gürel, E. (2001). Mikroçoğaltım. Bitki Biyoteknolojisi I. Doku Kültürü ve Uygulamaları, Babaoğlu, M., Gürel, E. ve Özcan, S. (edt.) 374 sayfa, 262-281.

Morini, S., and Perrone, S. (2006). Effects of short light dark regimes on in vitro shoot rooting of some fruit tree rootstocks. Biologia Plantarium. 50(3), 429־432. 
Muna, A.S., Ahmad, A.K., Mahmoud, K. \& Abdul-Rahman, K. (1999). In vitro propagation of a semi-drawfing cherry rootstock. Plant Cell and Tissue and Organ Culture, 59, 203-208.

Murashige, T., \& Skoog, F. (1962). A revised medium for rapid growth and bioassay with tobacco tissue cultures. Physiol. Plant. 15, 473-497.

Nguyen, Q.T. \& Kozai, T. (1998). Environmental effects on the growth of plantlets in micropropagation. Envir. Cont. in Biol. 36(2), 59-75.

Özzambak, E., \& Hepaksoy, S. (1997a). Investigations on in vitro proliferation of sour cherry cv. Heimanns Rubinweichsel. Acta Horticulturae. 447: 155ᄀ156.

Özzambak, E \& Hepaksoy, S. (1997b). Investigations on in vitro rooting and acclimatization of sour cherry cv. Heimanns Rubinweichsel. Acta Horticulturae. 447, 153-154.

Özzambak, E. \& Schmidt, H., 1991. In vitro and in vivo micrografting of cherry (Prunus avium L.) Gartenbauwissenschaft. 56(5), 221-223.

Paul, L. \& Feucht, W. (1985). Rooting sweet and sour cherry cultivar and clones in vitro. Hort. Abst. 55(9), 679.

Pevalek-Kozlina, B. \& Jelaska, S. (1987). Microclonal propagation of Prunus Avium L. symposium on in vitro problems related to mass propagation of horticultural plants. ISHS Acta Hort. 212, 599 602.

Pontikis, C.A. \& Melas, P. (1986). Micropropogation of Ficus carica L. Hort Science, 21(1), 153.

Pospisilova, J., Ticha, I., Kadlecek, P., Haisel, D. \& Plzakova, S. (1999). Acclimatization of micropropagated plants to ex vitro conditions. Biologia Plantarum, 42(4), 481-497.

Ruzic, D., Cerovic, R. \& Ystaas, J. (1998). Influence of agar brands and concentration on in vitro shoot multiplication of the cherry rootstock Gisela 5. Acta Hort. 468, 209-216.

Ruzic, D., Saric, M., Cerovic, R. \& Culafic, L. (2000). Relationship between the concentration of macro elements, their uptake and multiplication of cherry rootstock Gisela 5 in vitro. Plant cell, tisue and organ culture, 63, 9-14.

Sauer, A. (1985). In vitro propagation of Prunus avium L. and storage of in vitro derived plantlets. Acta Horticulture, 169, 351.

Snir, I. (1982). In vitro propagation of sweet cherry cultivars. Hort Science, 17, 192-193.

Solarova, J. \& Posposilova, J. (1997). Effect of carbon dioxide enrichment during in vitro cultivation and acclimatization to ex vitro condition. Biologia Plantarum. 39(1), 23-30.

Tang, H.R., Ren, Z.L., Renstle, G. \& Krczal, G. (2002). Plant regeneration from leaves of sweet and sour cherry cultivars. Sci. Horticulture, 93, 235-44. 